\title{
أثر ( تُبّع وفتوحاتهم )
}

\author{
مثنى محمد حميد \\ كلية والجامعة : معهد التاريخ العربي للدراسات العليا
}

ان الهدف من بحثي بيان نهوض الأمم وسقوطها والتحديات التي تواجهها . فالأمم تهض قوية نتيجة قساوة الأحداث وتجرعهم

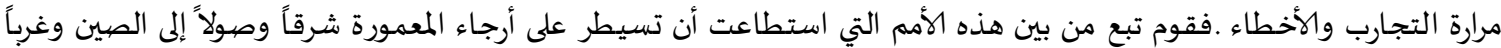

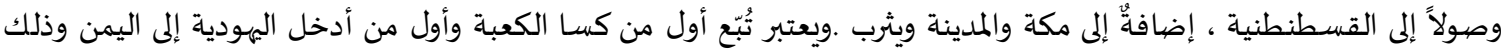

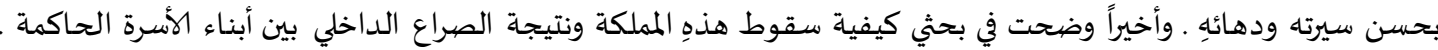

المقدمة

الحمد لله الذي خلق القلم قبل كل شيء ، وقال له : أُكتب ، قال : ما اكتب ؟ قال : اكتب ما كان وما يكون وما هو كائن إلى يوم

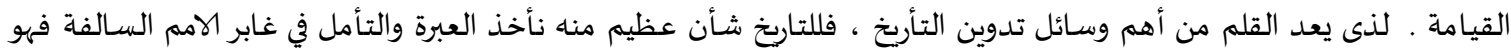

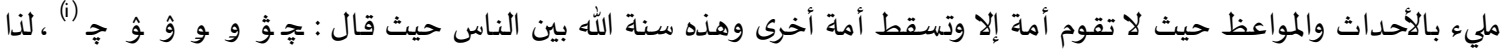

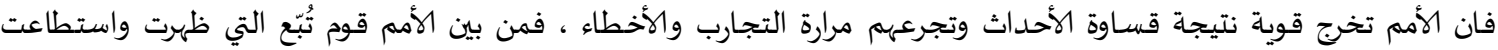

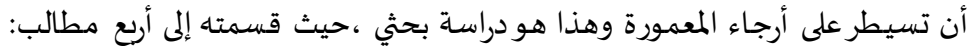

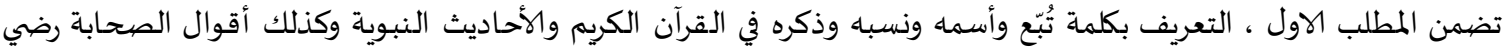

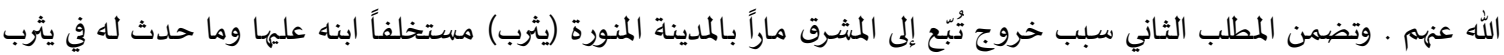

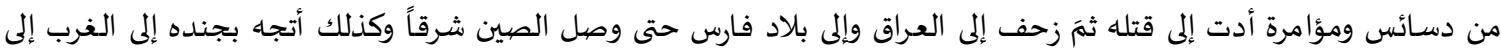

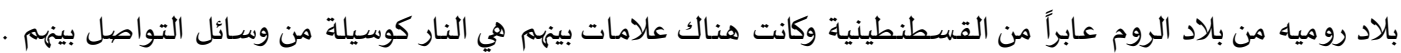

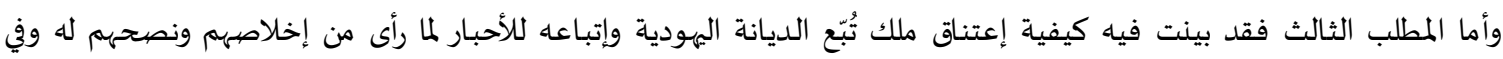

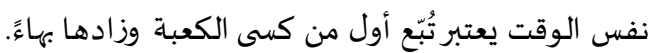

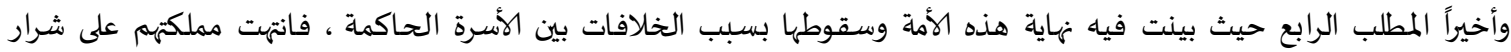
الخلق ـ واخيراً ختمت بحثي بخاتمة استخلصت فهها اهم الدروس والعبر من هذا البحث واسأل الله العظيم أن أكون قد وفقت

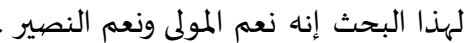

$$
\text { المطلب الاول }
$$

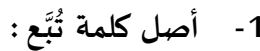

ليس المراد باه رجلاً واحداً بعينه ، بل ألمَ المراد به ملوك اليمن وتُبَّع لقب للملك ، كالخليفة للمسلمين ، وكسرى للفرس ، وقيصر

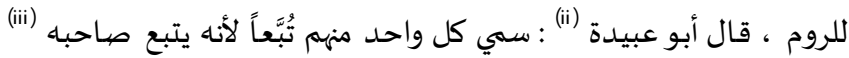
قال الجوهري (iv) : والتبابعة هم ملوك اليمن ، واحدهم تُبَّع . 


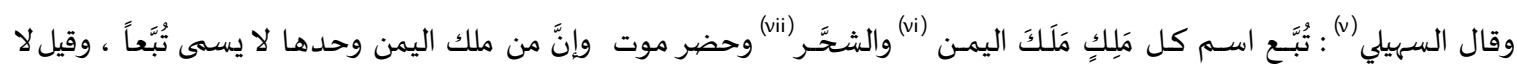

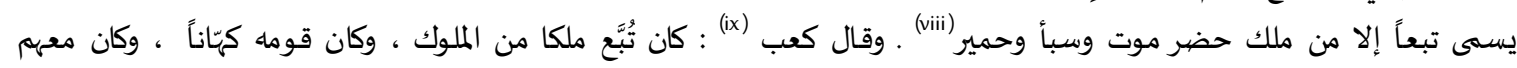

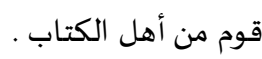

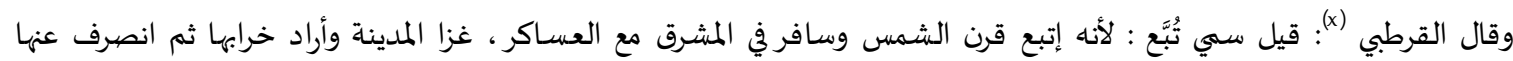

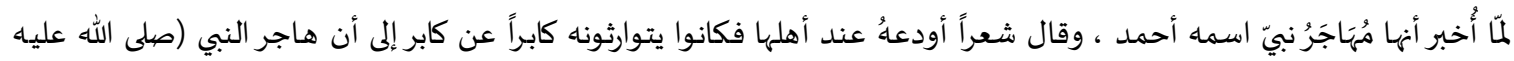

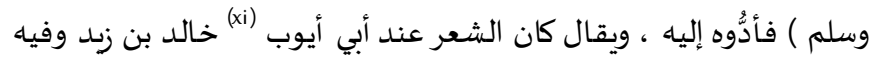

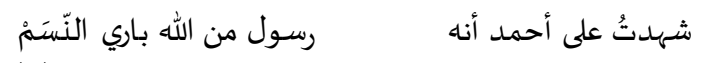

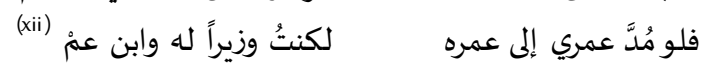

2- نسبه :

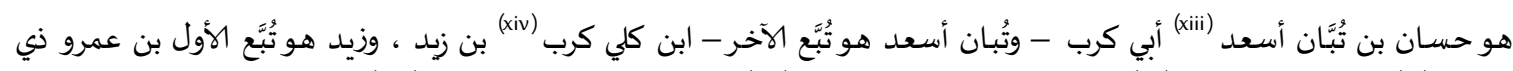

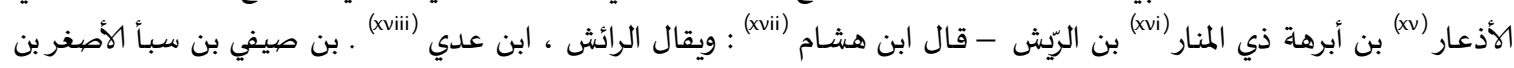

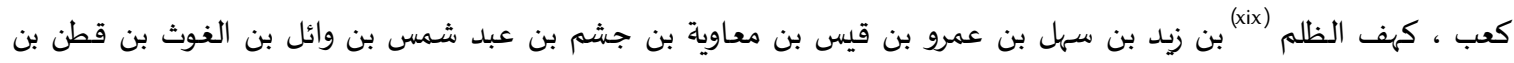

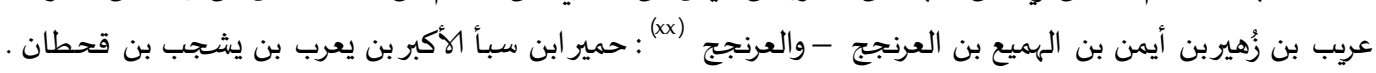

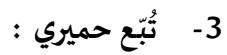

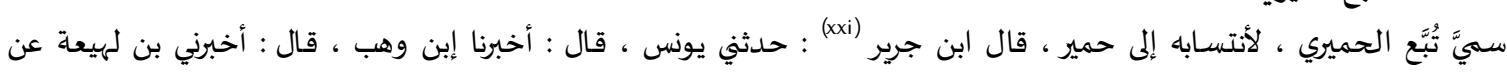

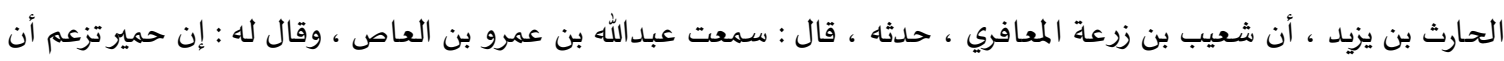

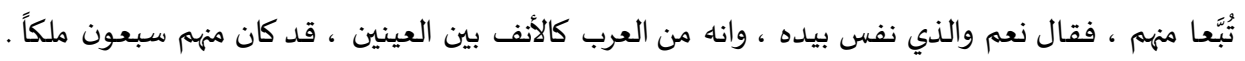

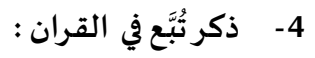

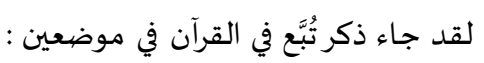

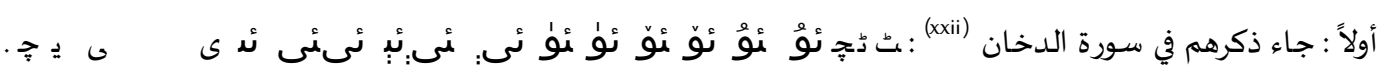

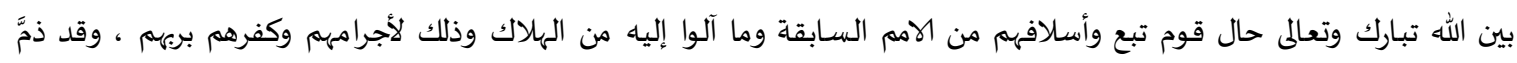

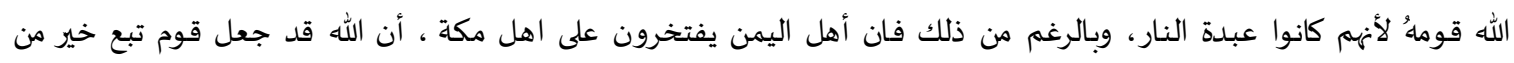

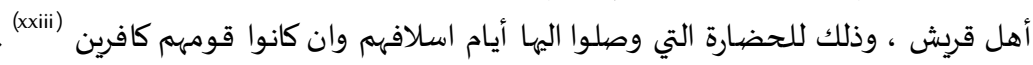

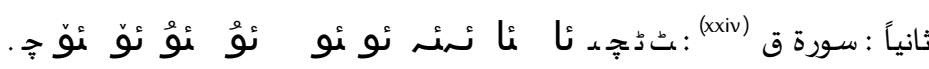

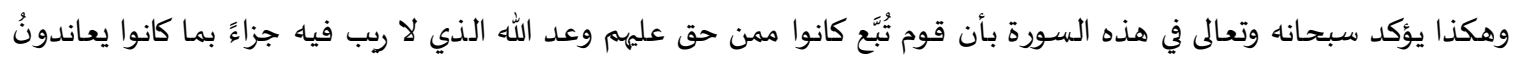

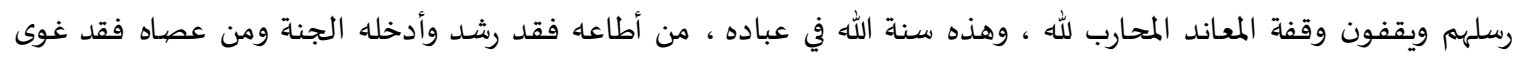
وادخله النـار (xxv).

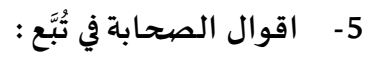

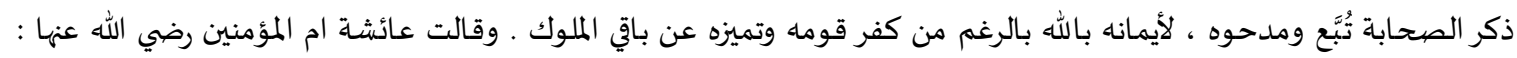

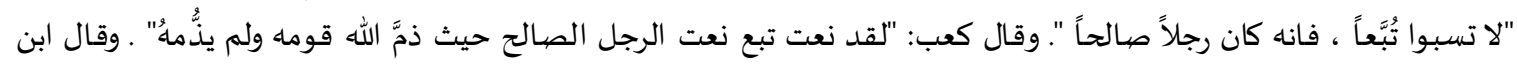

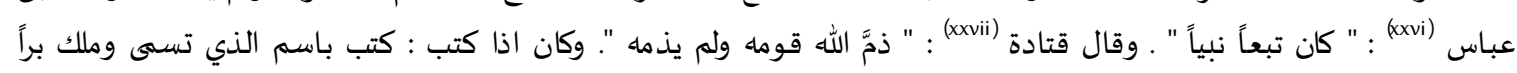

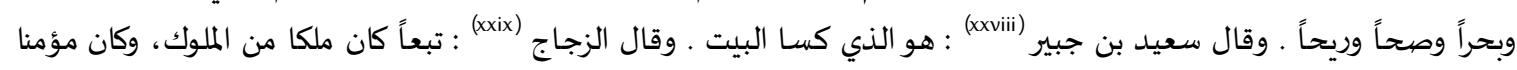
وقومه كافرون .

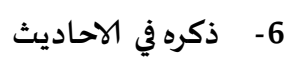

وردت أحاديث بمدح تبّع وصلاحه ولأنه آمن دون غي آديره من قومه إذ لم يتبعوه .

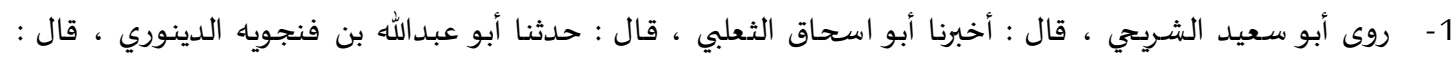

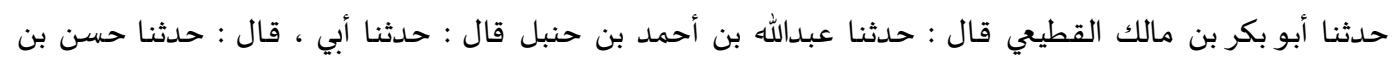


موسى ، قال : حدثنا إبن لهيعة ، قال : حدثنا أبو زرعة بن عمرو بن جرير قال : عن سهل بن سعد ، قال : سمعت

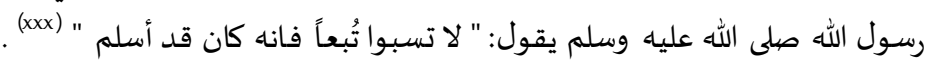

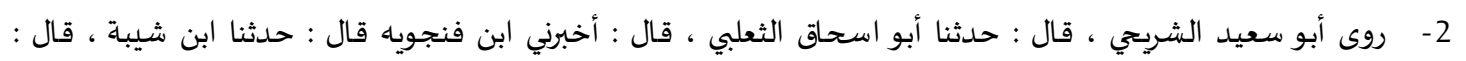

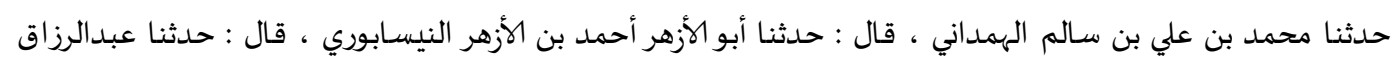

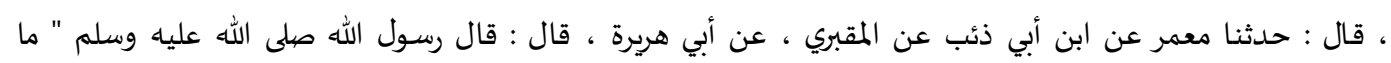

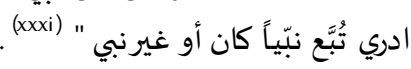

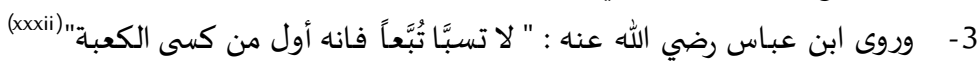

$$
\text { 1 المطلب الثاني }
$$

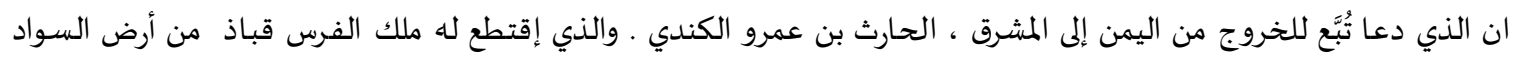

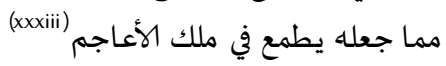

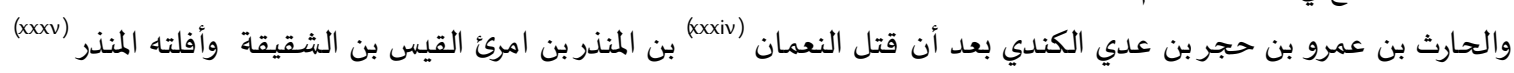

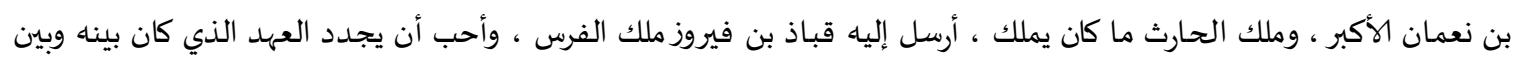

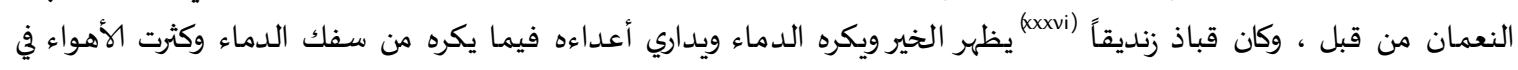

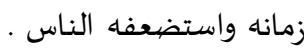

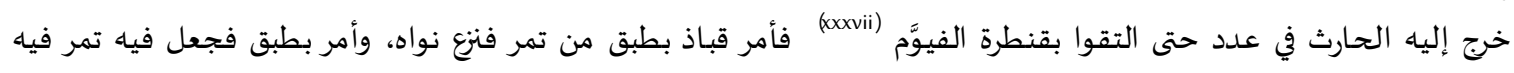

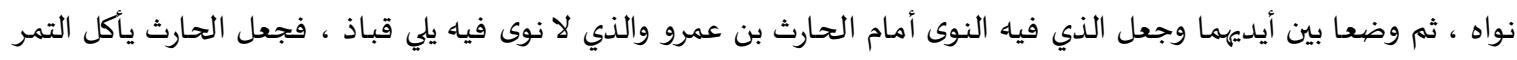

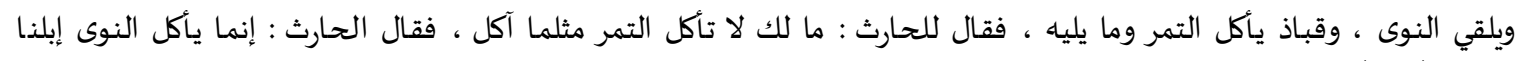

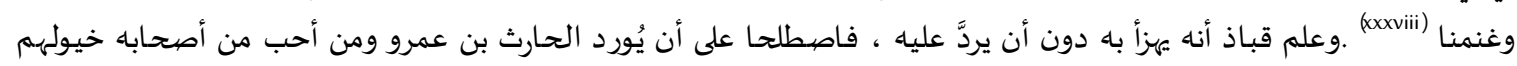
الفرات إلى ألباها ،ولا يجاوزا اكثر من ذلك.

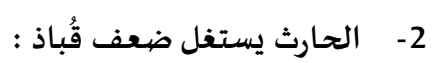

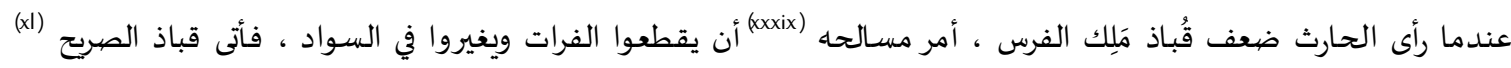

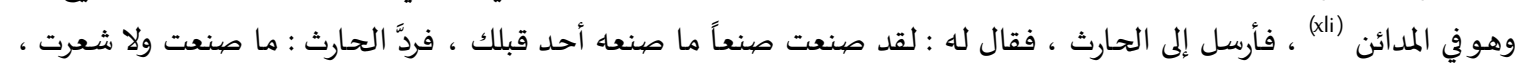

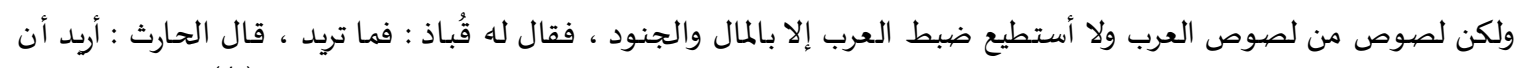

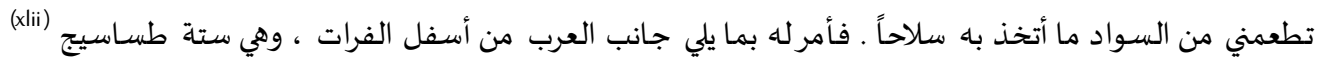

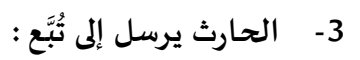

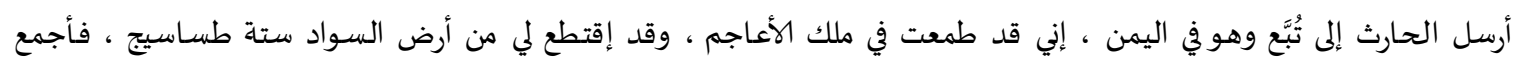

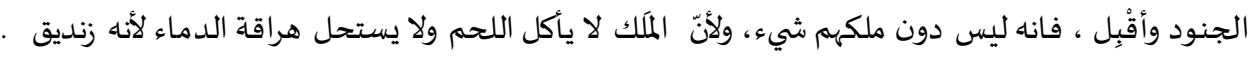

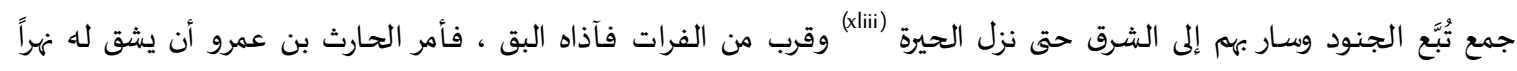

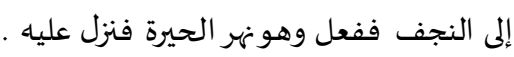

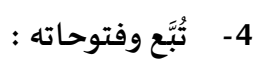

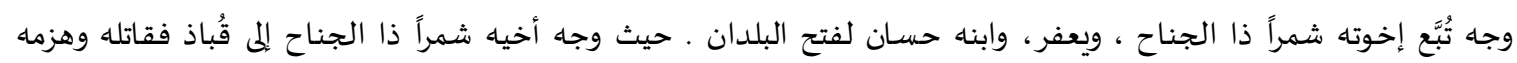

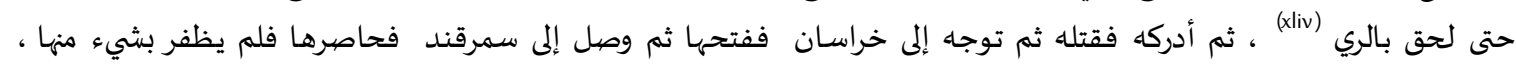

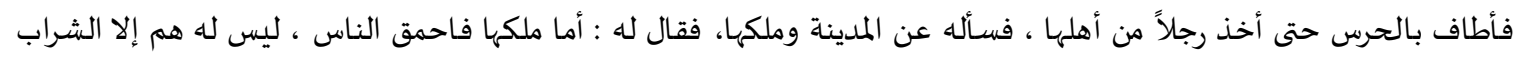

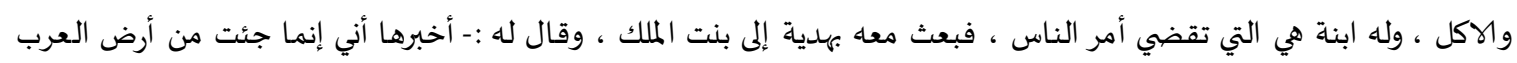

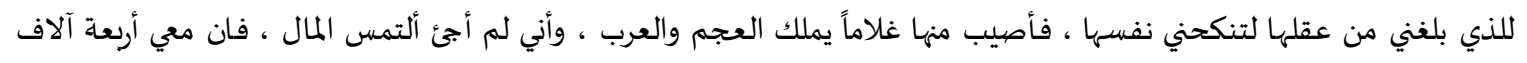


تابوت من ذهب وفضية هاهنا ، فأنا أدفعها إلهها وأمضي إلى الصين ، فان كانت لي الارض كانت امرأتي ، وان هلكت كان ذلك المال ، فال

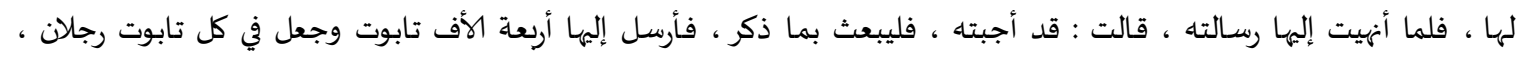

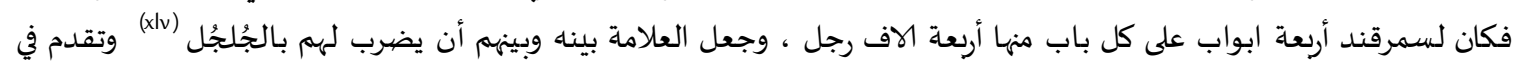

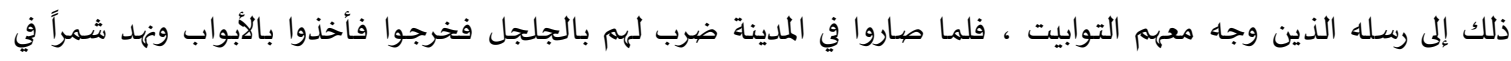

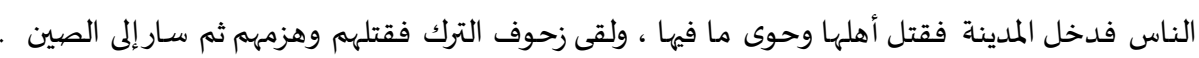

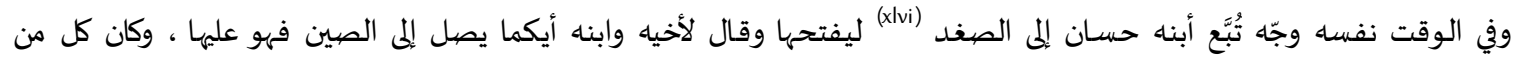

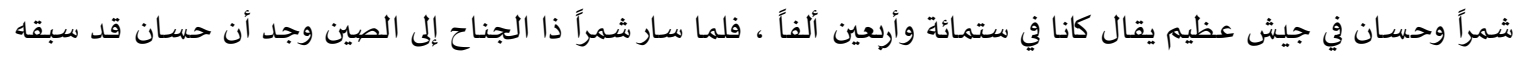

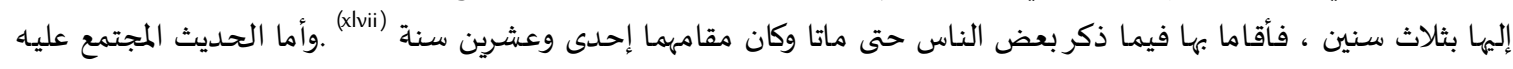

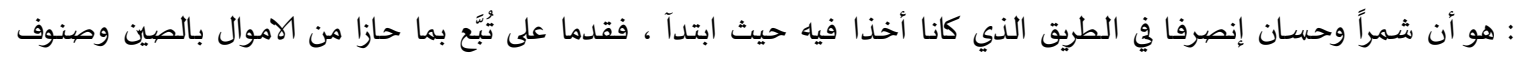

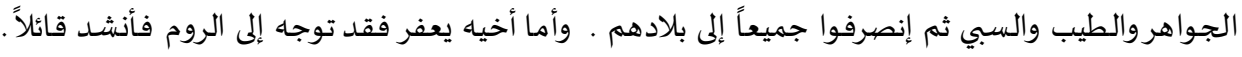

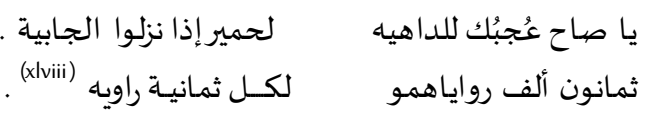

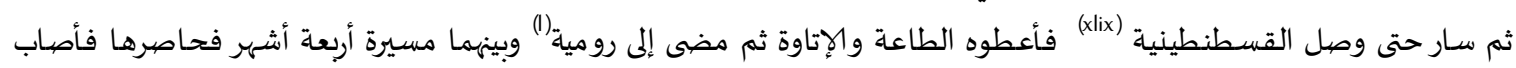

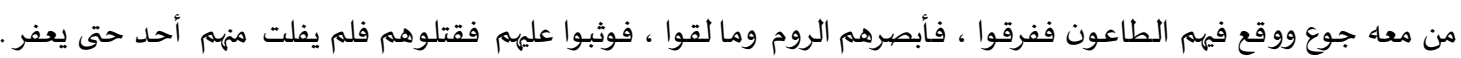

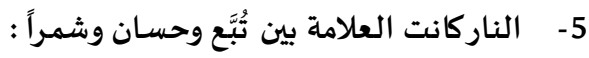

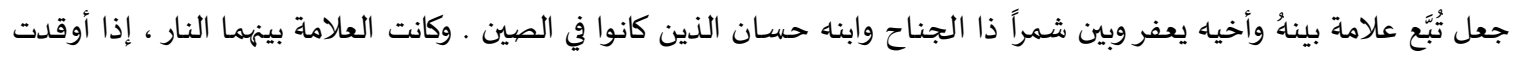

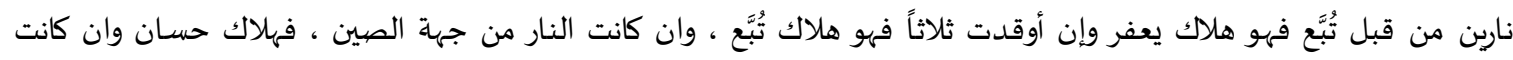

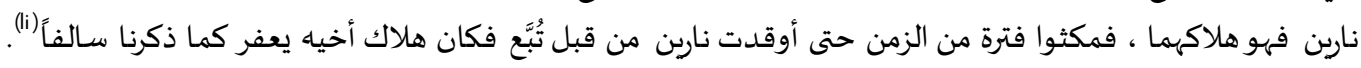

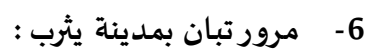

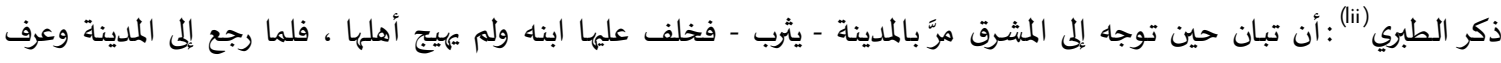

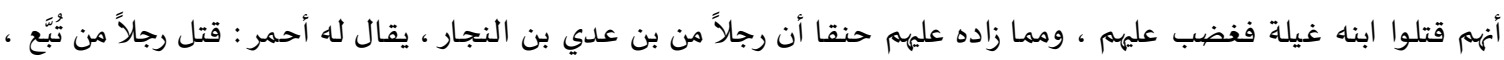

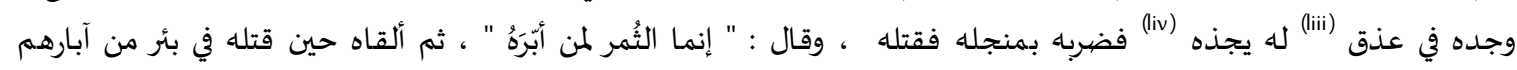

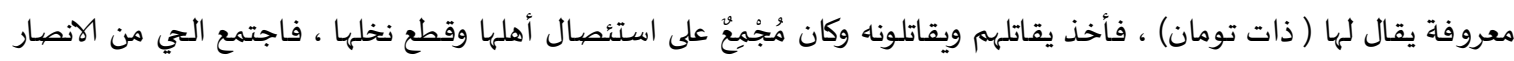

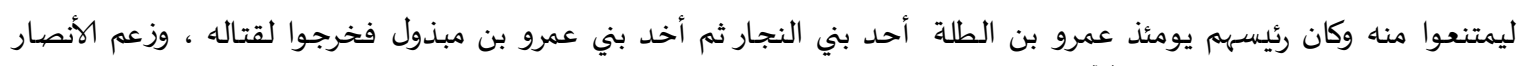

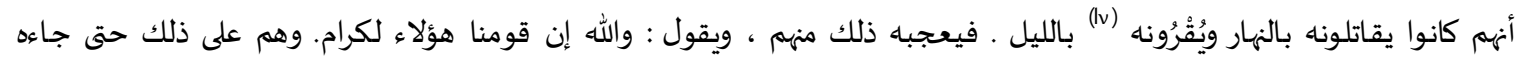

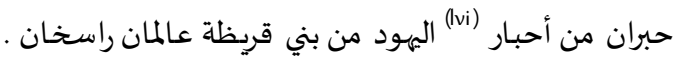

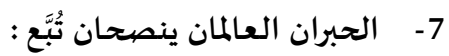

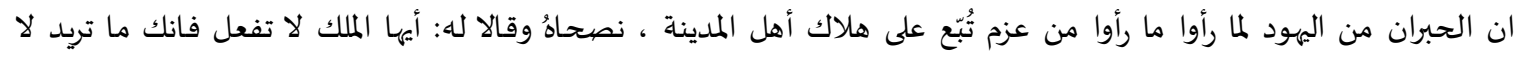

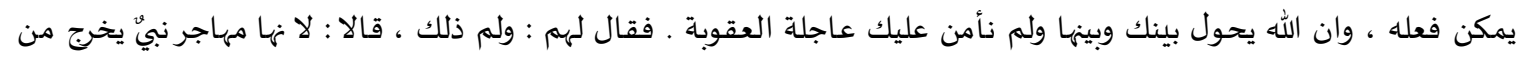

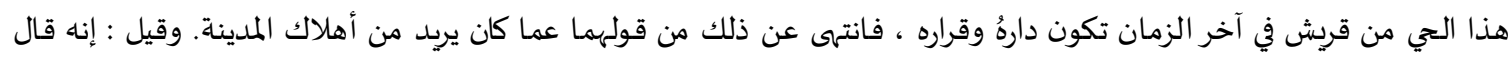

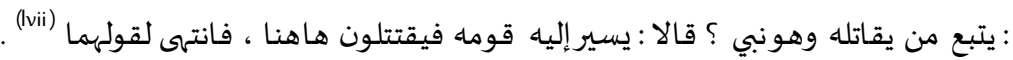
المطلب الثالث

\section{1}

لما رأى نصيح الحبرين له ، وغزارة علمهما أعجبه ما سمع منهما لهوديه ، وخرج بهما معاه إلى اليمن بعد أن اتبع دينهما وكان اسم الحبرين

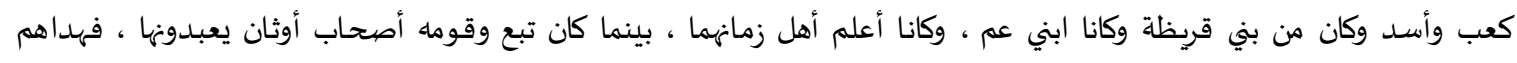
الله 


\section{2- ت تُبَّع ونفر من هذيل :}

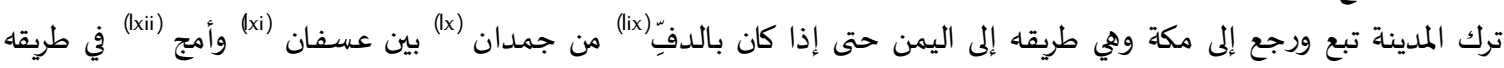

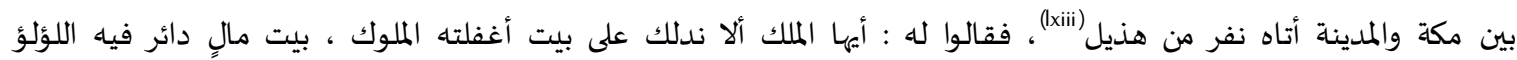

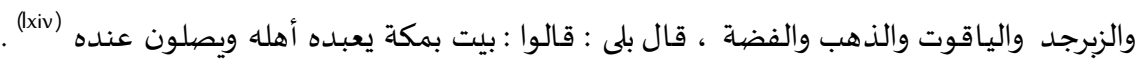

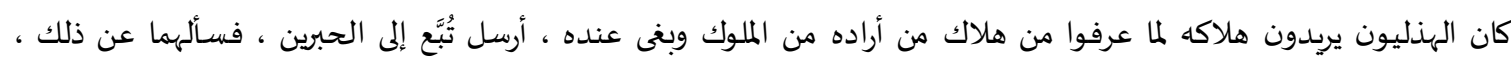

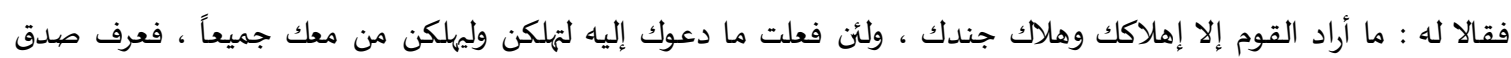

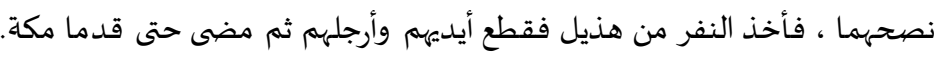

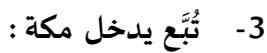

بعد أن سمع من الحبران نصحهما ، وما كادَ له الهذليون : سأل الحبران ما أصنع في البيت : قالاله له ، تصنع ما يصنع أهله تطوف

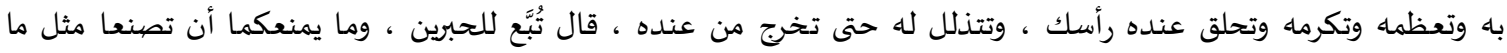

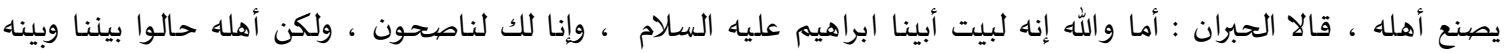

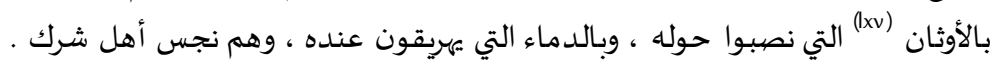

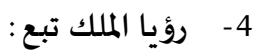

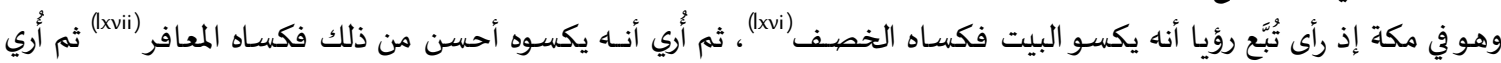

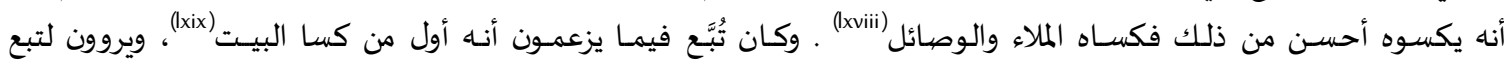
حين كسا البيت أنه قال شعراً :

$$
\begin{aligned}
& \text { الله ملاءً منضــــاً وبروداً } \\
& \text { وجعلنــا لبابــا إقليدا } \\
& \text { فترى الناس نحوهنَّ ورودا } \\
& \text { فرفعنــا لواءنـا معقودا (lxx) }
\end{aligned}
$$

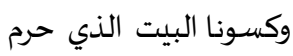$$
\text { فأقمنا به من الشهر عشراً }
$$

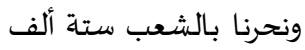$$
\text { ثم سرنا عناه نؤم مهيلاً }
$$

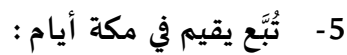

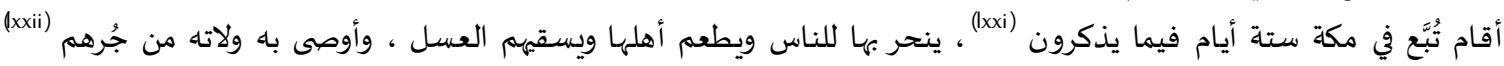

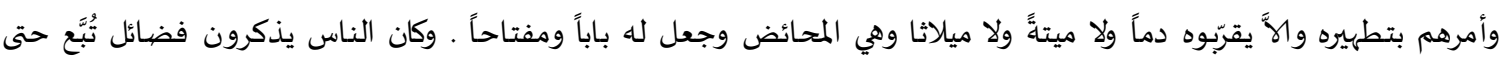

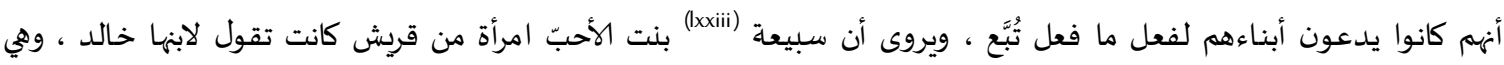

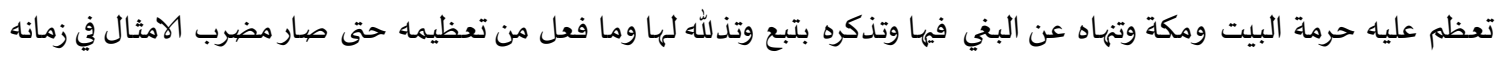

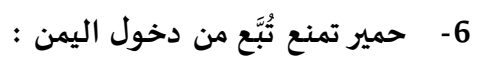

روى الطبري (1xiv) ، قال : حدثع تئع من دخول ابن حميد ، قال : حدثنا سلمة ، عن ابن إسحاق عن أبي مالك بن ثعلبة بن أبي مالك القرظي ،

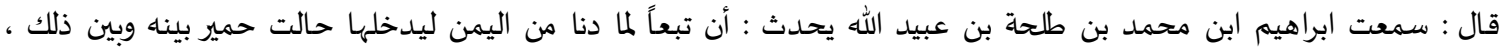

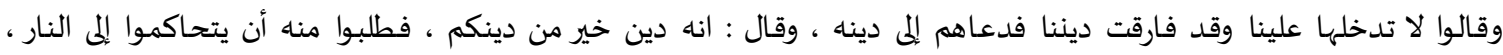

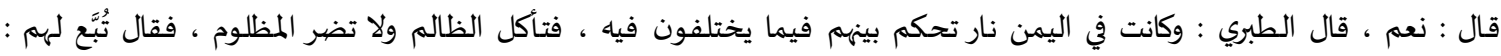

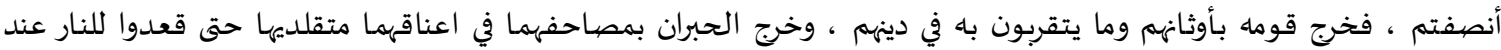

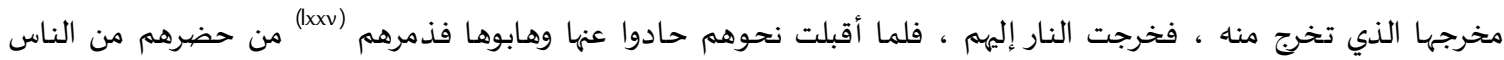

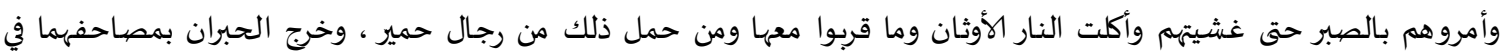

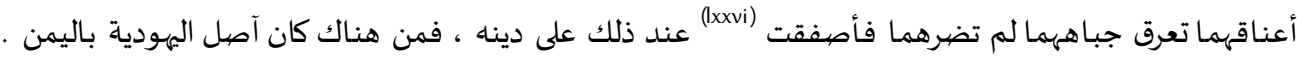

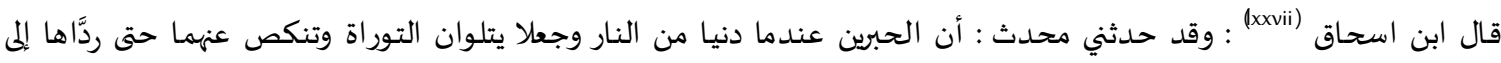
مخرجها الذي خرجت منه فأصفقت عند ذلك حمير على دينهما . 


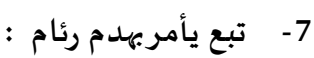

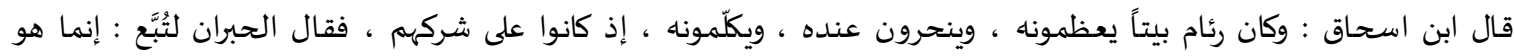

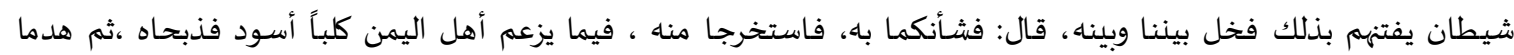

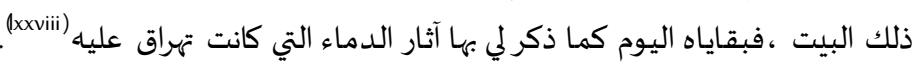

المطلب الرابع

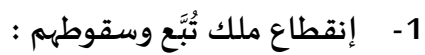

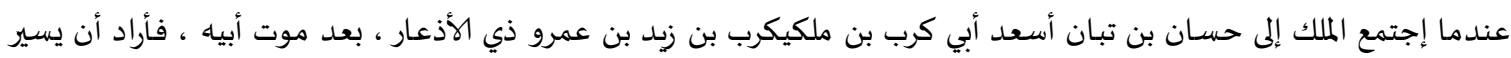

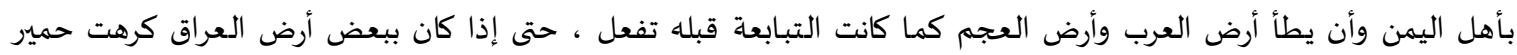

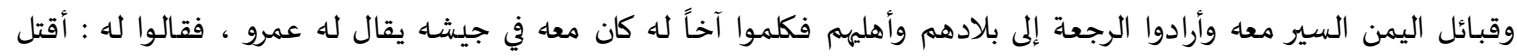

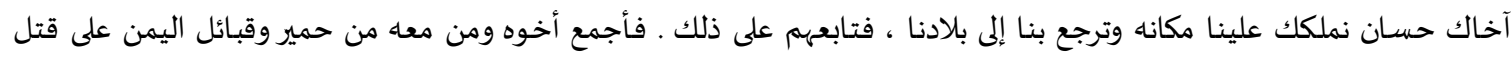

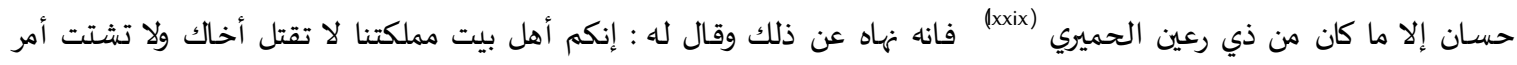

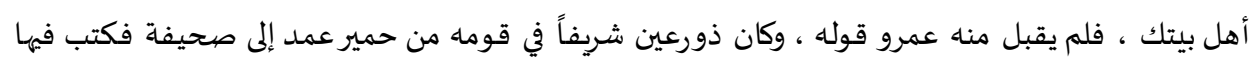

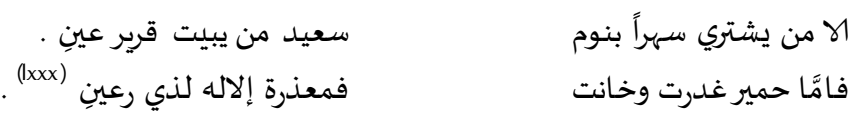

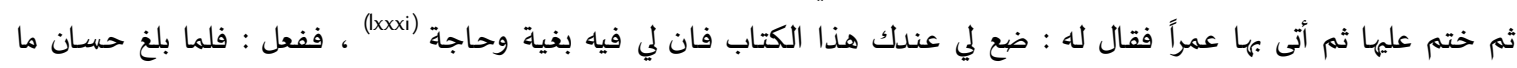

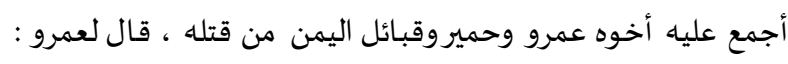

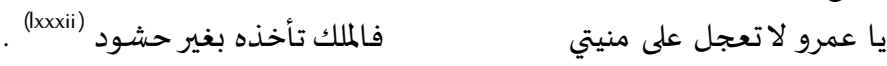

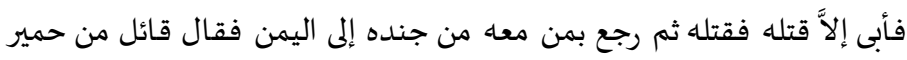

$$
\text { قتيلا في سالف الأحقاب }
$$

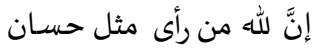

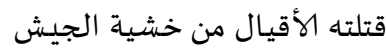

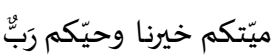

\section{2- عقوبة الله لعمرو :}

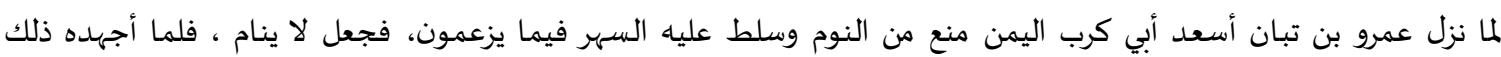

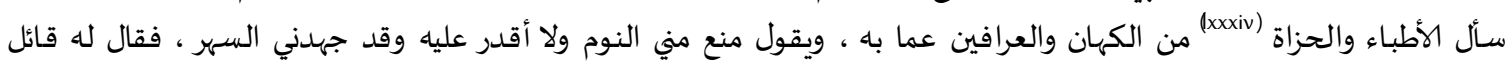

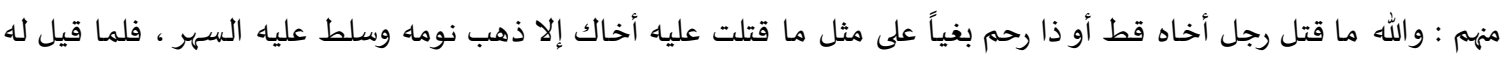

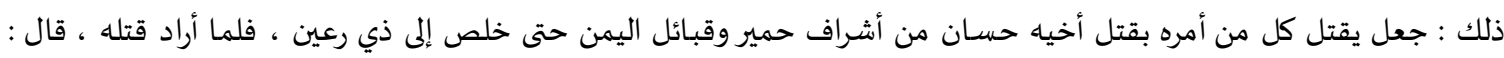

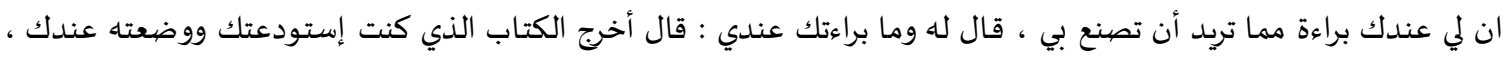

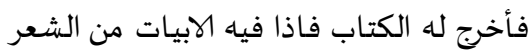

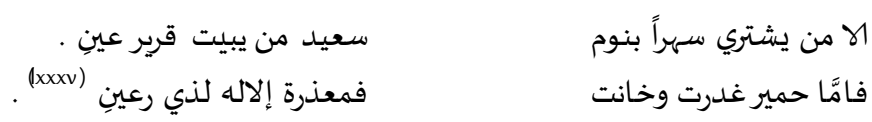

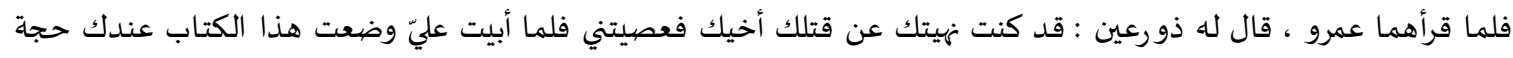

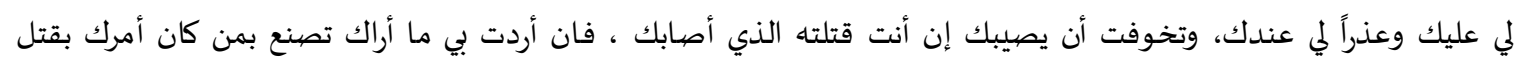

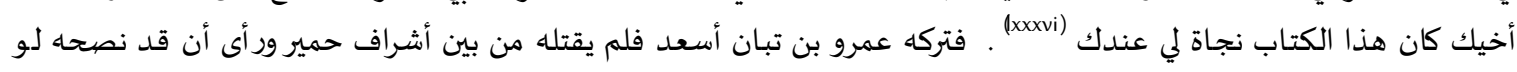

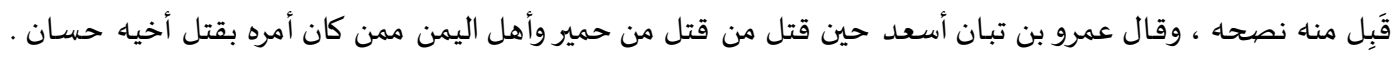

$$
\text { وقدس برزت معاذيـد وعقد غير بيـن . }
$$

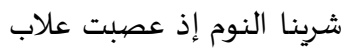

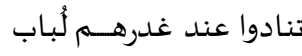




$$
\begin{aligned}
& \text { بواءً بابن رهم غير ديسـن . } \\
& \text { وحسـان قتيل الثائربــنـن . } \\
& \text { ومرّت عند ذاكم كل عيسن . }
\end{aligned}
$$$$
\text { إذا قال المقاول أين أيــن . }
$$$$
\text { (xxxvii) }
$$$$
\text { وكان المكر حينهم وحينـي . }
$$$$
\text { غواة أهلكوا حسبي وزيني المكر حيني وحيني }
$$

قتلنا من تولى المكر منهـمـم

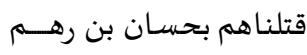

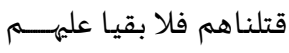

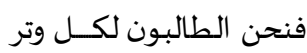

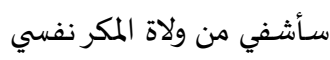

أطعتهم فلم أرشد وكانـــوا

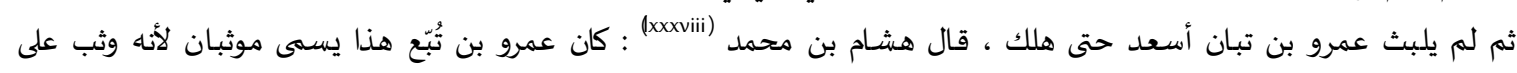

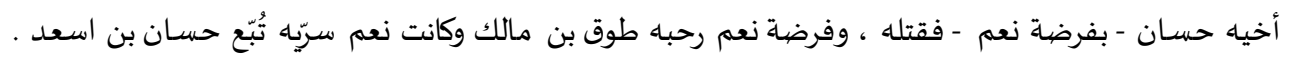
3-

بعدما هلك عمرو ، قال ابن اسحق : خرج أمر حمير وتفرقوا ، فوثب عليهم رجل من حمير لم يكن من بيوت المملكة منهم يقال لله

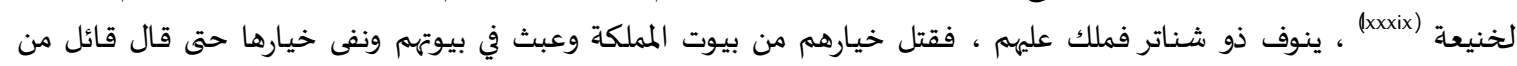

$$
\text { تقديّل }
$$

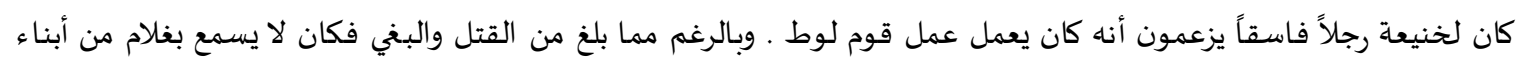

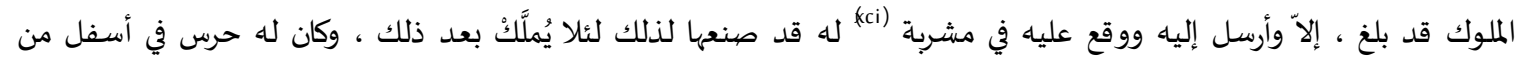

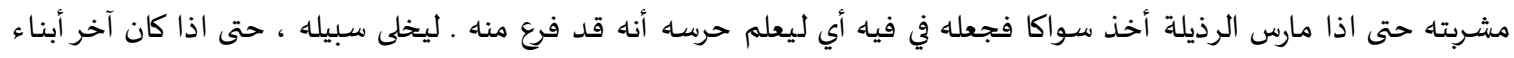

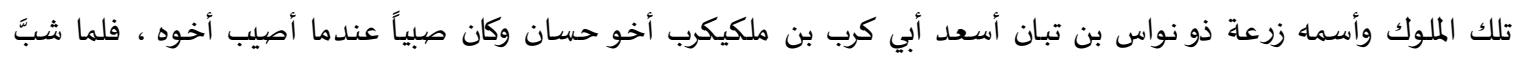

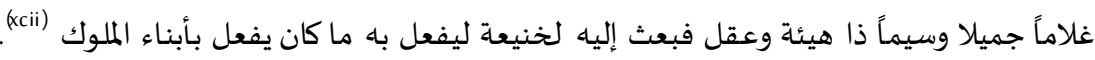

\section{4- زرعة ذو نؤاس ولخنيعة :}

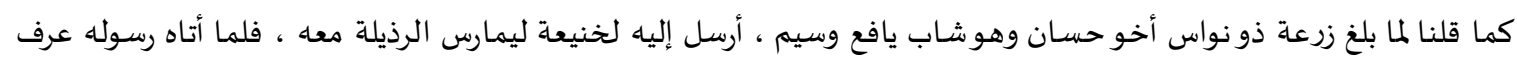

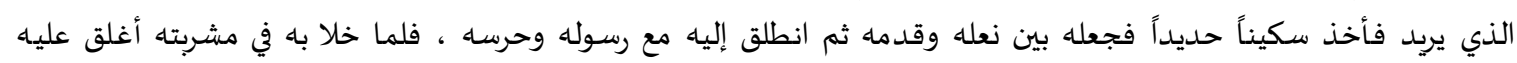

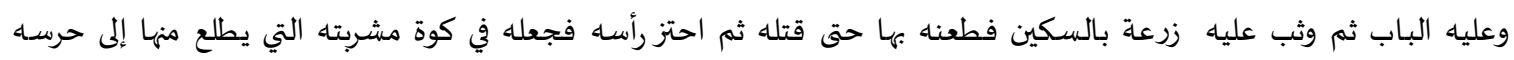

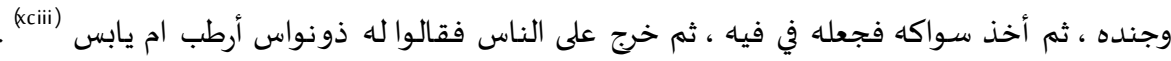

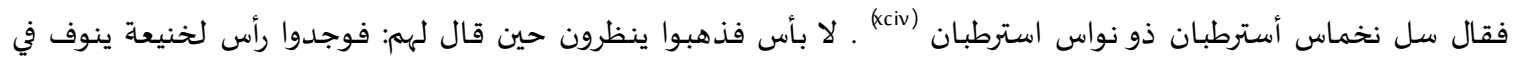

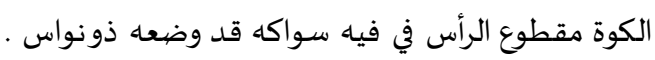

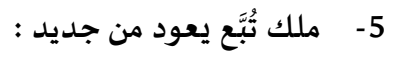

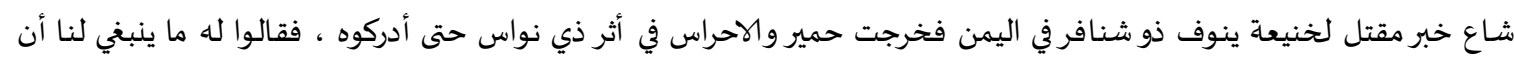

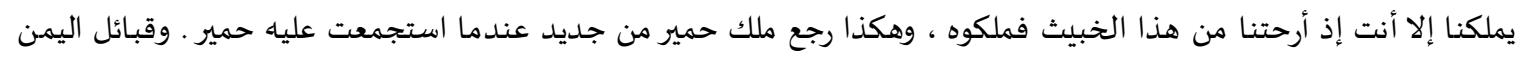

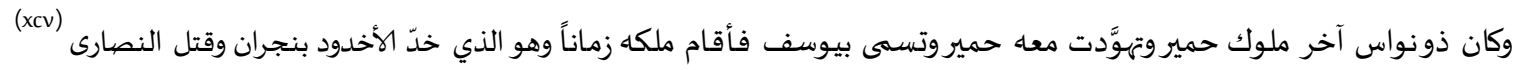

الخاتمة - الخما

أن من أهم النتائج المستخلصة من بحثي هذا :

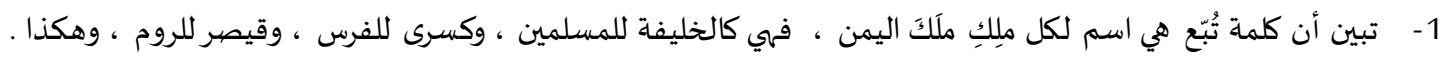

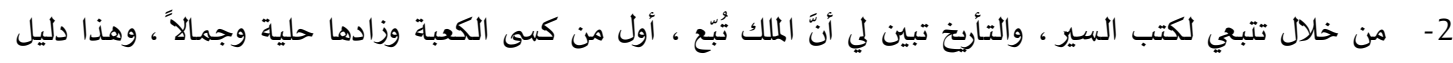

$$
\text { على سعت ملكه وكرمه . }
$$




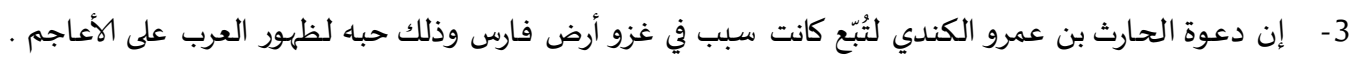

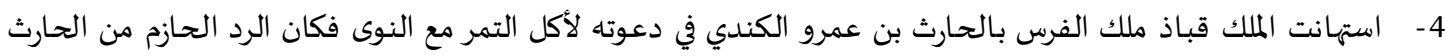

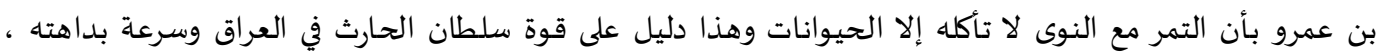

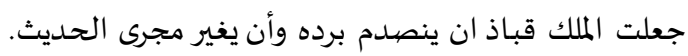

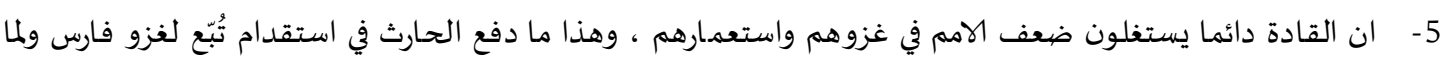

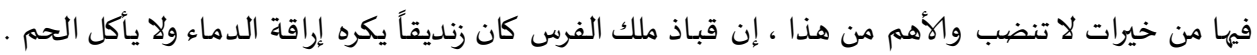

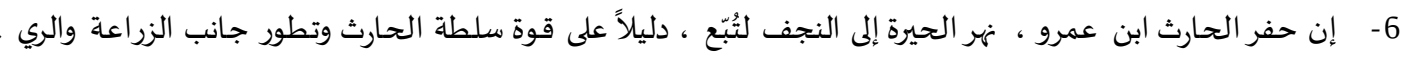
7وكان سبباً في دخوله الديانة الههودية .

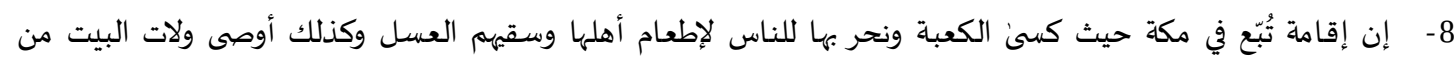

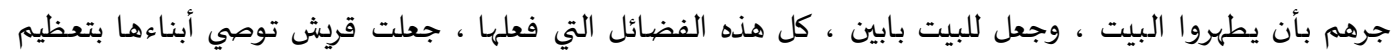

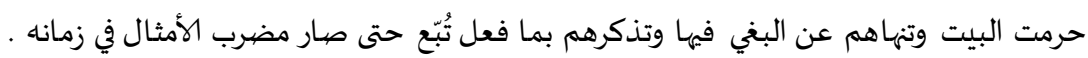

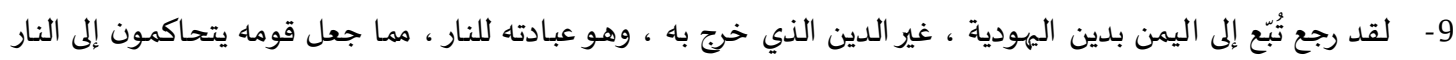

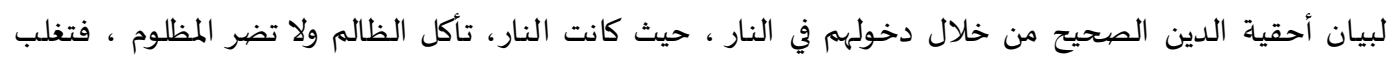

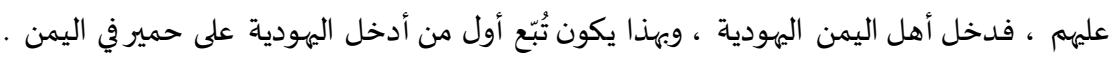

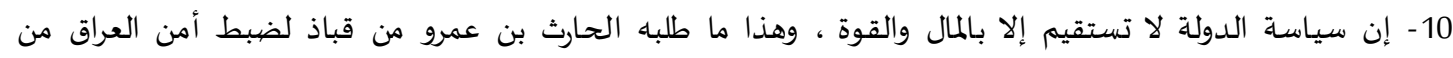

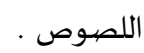

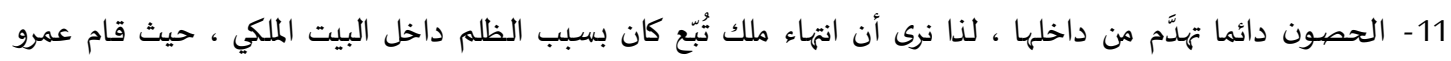

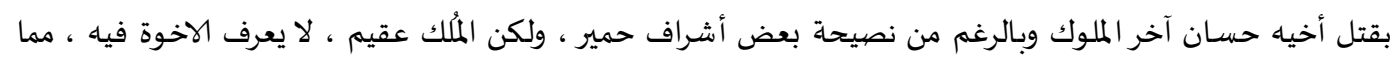

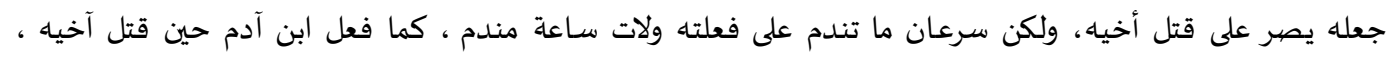

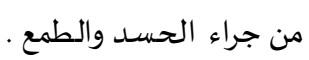

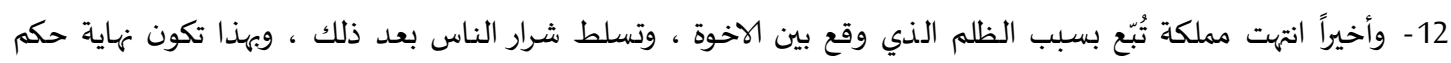
حقب تُبَّع . ن. الهوامش :

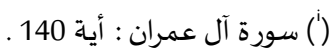

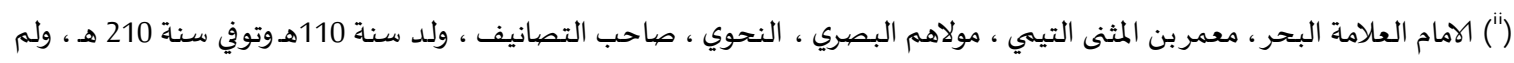

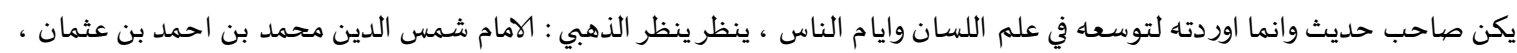

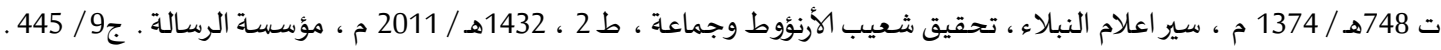

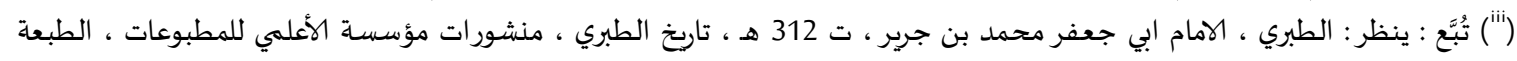

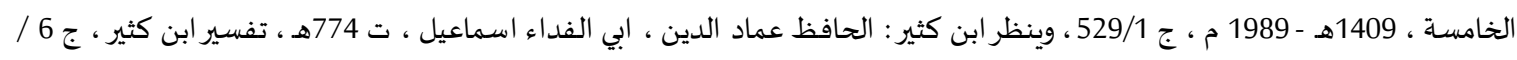

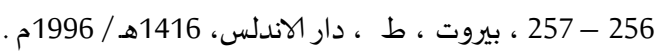

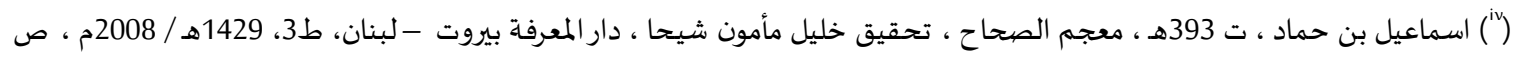

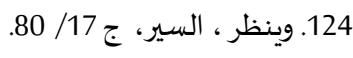


(") السهيلي : هو الامام ابو زبد العلامة الاندلسي الحافظ العلم ، صاحب التصانيف منها ( الروض الانف في شرح سيرة ابن هشام ) ينظر:

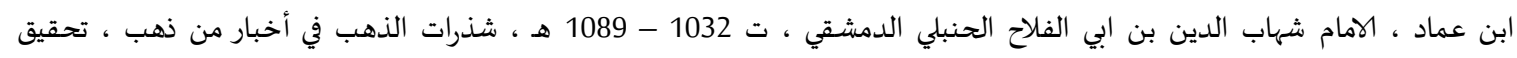

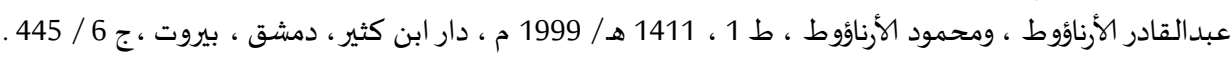

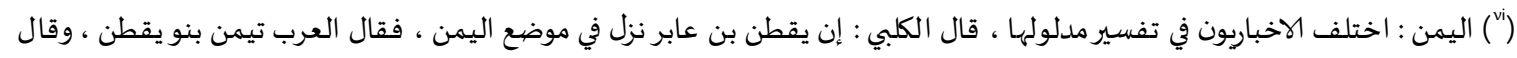

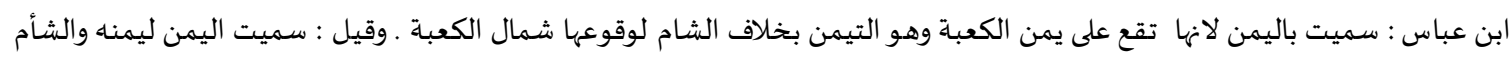

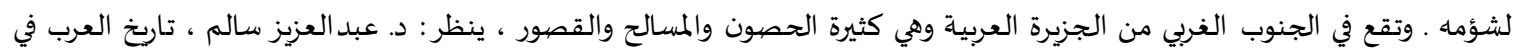

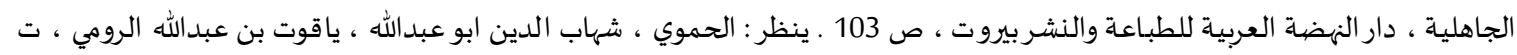

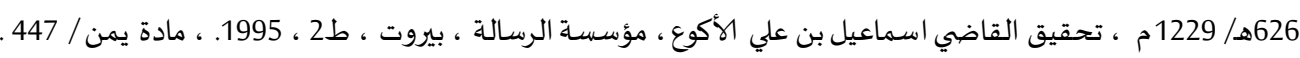

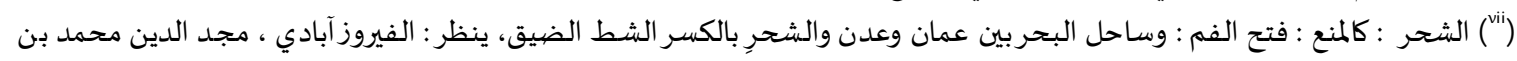

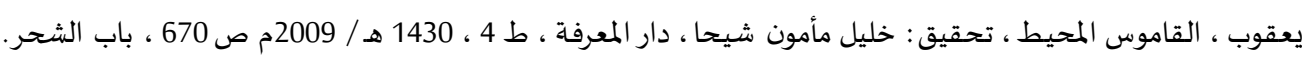
("iii)

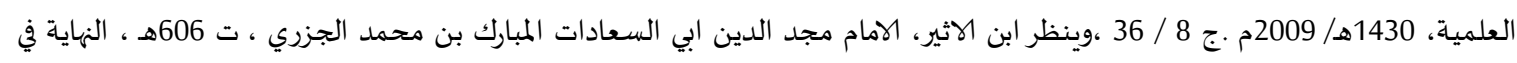

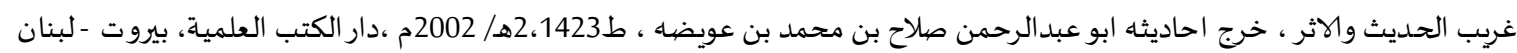
.177/1

(x) كعب : هو كعب بن ماتع : بكسر المثناة من فوق ، الحميري ، ابو اسحاق ، المعروف بكعب الاحبار ، من آل ذي رعين ، ينظر : ابن حجر ،

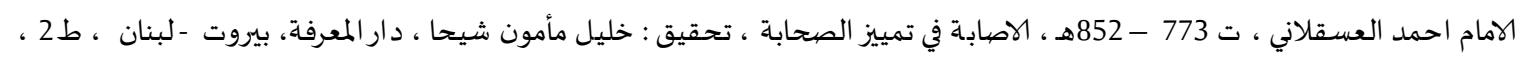

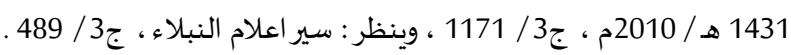

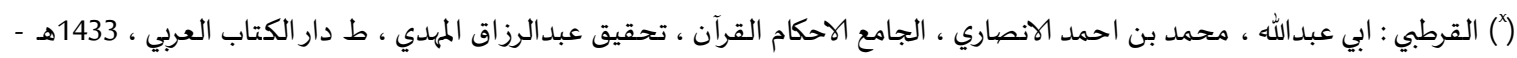

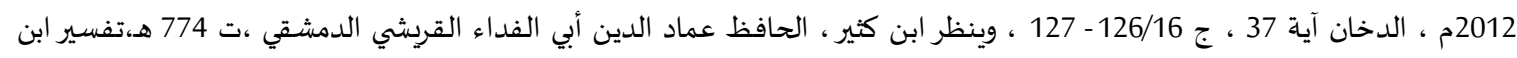

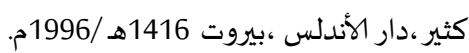

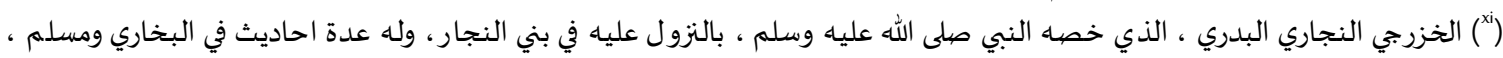

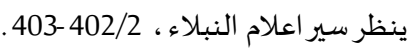

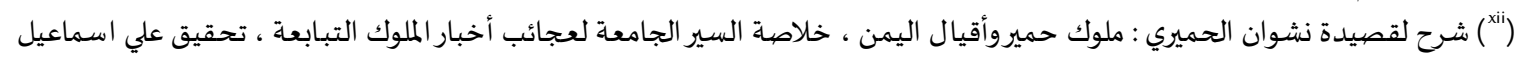

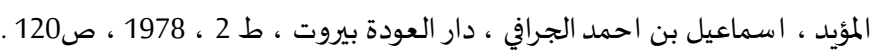

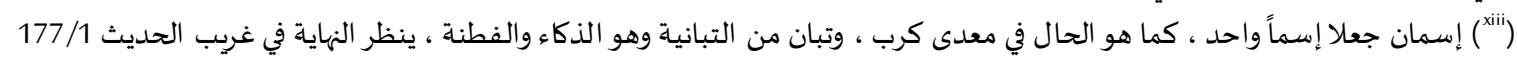

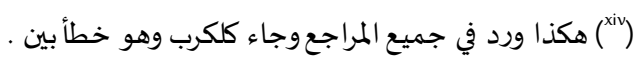

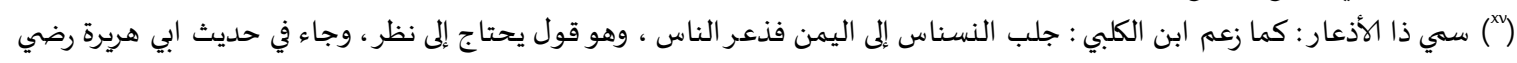

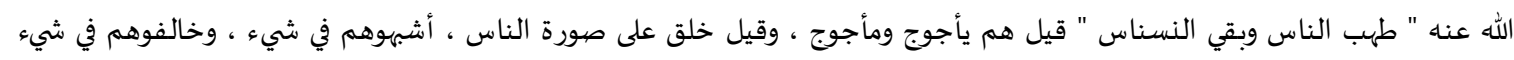

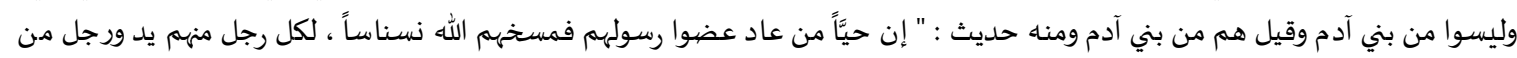

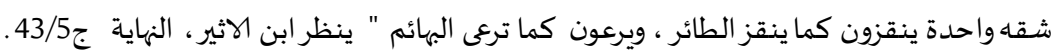

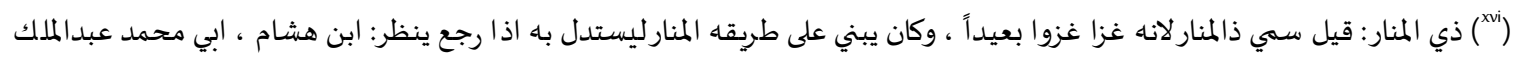

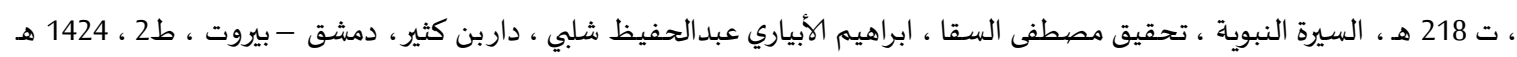

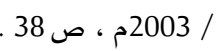

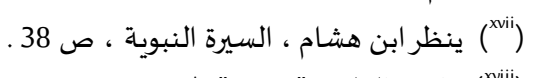

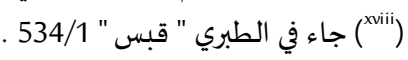

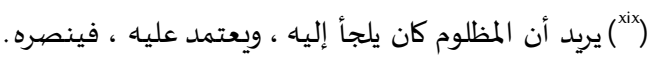

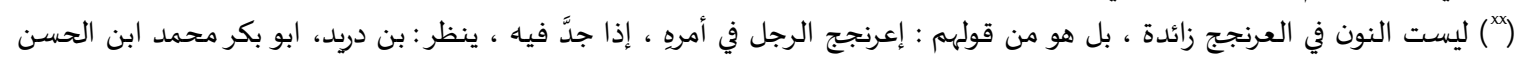

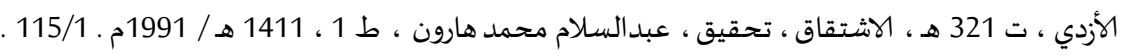


( 1 ، الطبري : أبي جعفر، محمد بن جرير ، ت 312 ، جامع البيان من تأويل أي القرآن ، المعروف تفسير الطبري ، دار إحياء التراث العربي ،

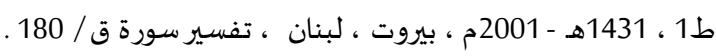
. 37 : (cxii) 151/25 سنظر تفسير الطبري : (xiii) سورة ق : آية 14 (xiv)

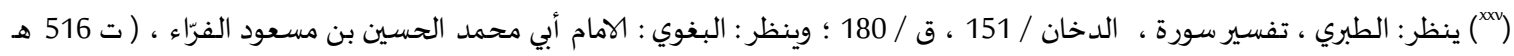

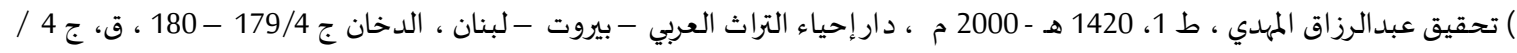

(

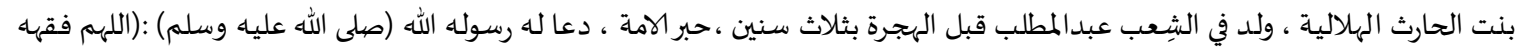

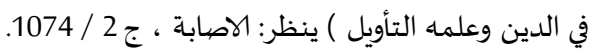

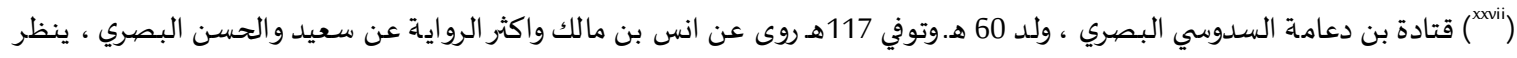

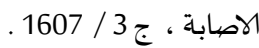

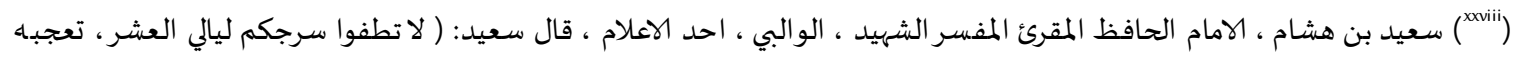

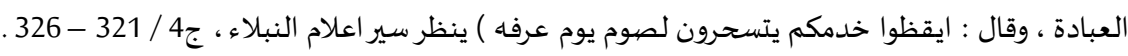

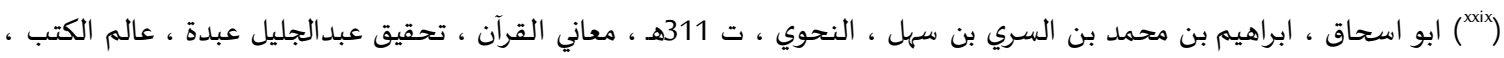

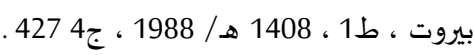

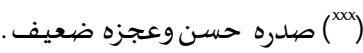

إسناده ضعيف جداً ، إبن لهيعة ضيعيف ، وعمره خعرو متروك ، ولصدره شواهد يحسن بها والله أعلم.

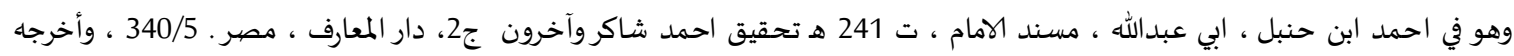

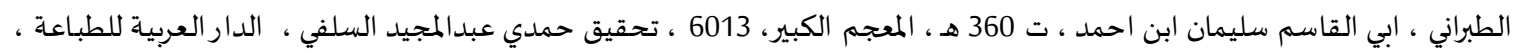

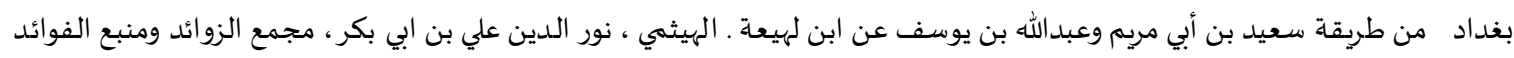

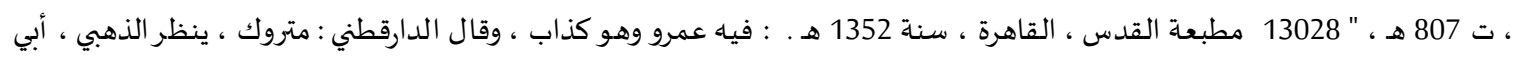

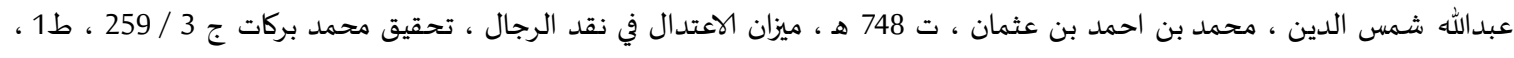

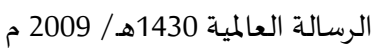

وقال الحافظ في " الكشاف " 279/4 : فيه ابن لهيعة عن عمرو بن جابر ، وهما ضعيفان والصهواب أن عمرو متروك وقال أحمد بلغني أنه يكذب راجع الميزان وورد عن الطبري 31143 عن قتادة قال : " ذكر لنان تبعاً ... " ولم يرفعه وورد النهي عن سبه دون لفظ " فانه أسلم " فئري

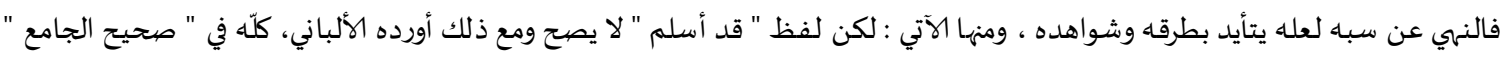

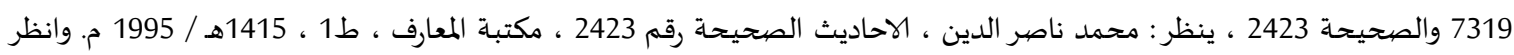

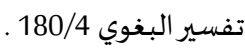

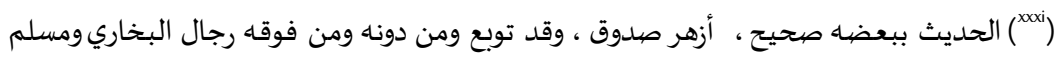

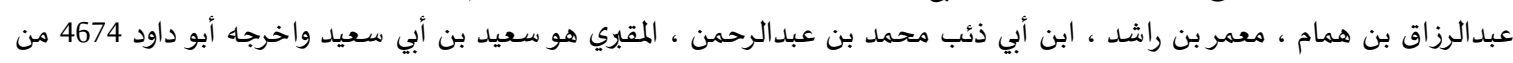

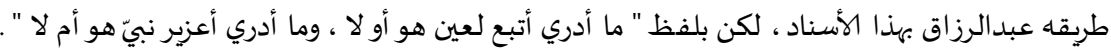

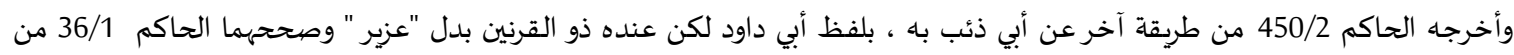

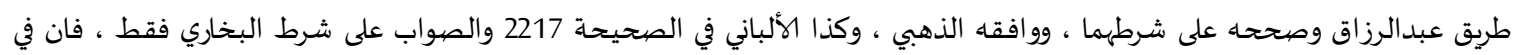

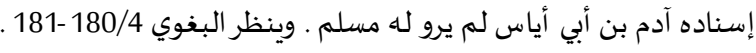
(xxii) ، ينظر الطبري ، التاريخ ، 10 (xxiii) 
( الملقب ابي قابوس ( 582 - 609هـ ) ) كان مسيحياً نسطوريا تسلم الحكم بعد أبيه ، من أشهر ملوك المناذرة قبل الاسلام ، داهية

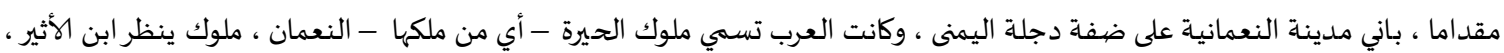

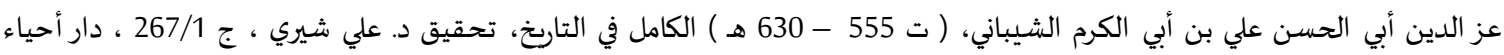

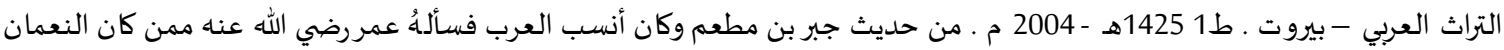

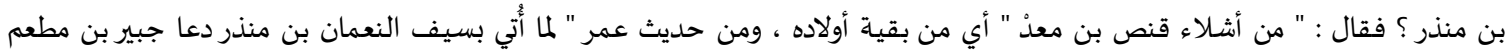

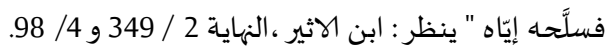

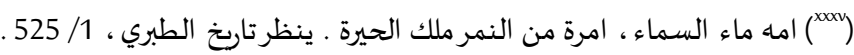

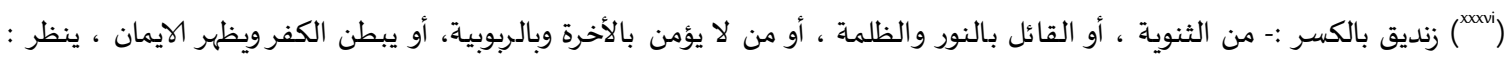

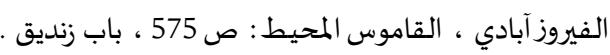

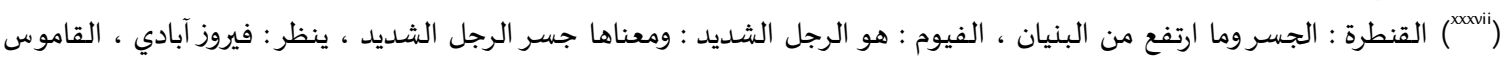

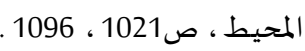
(xxoviii)

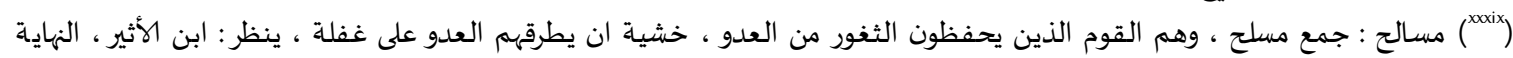

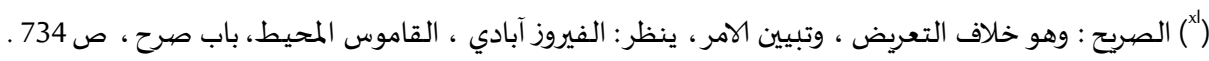

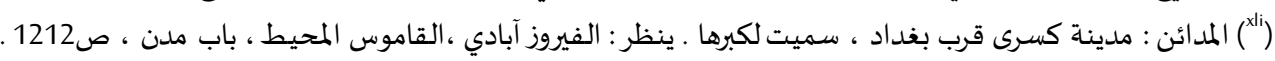

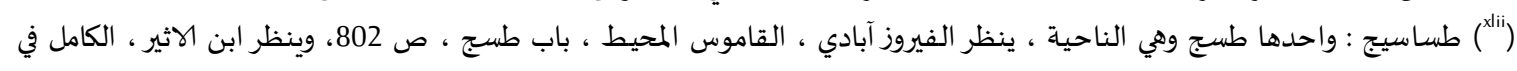

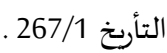

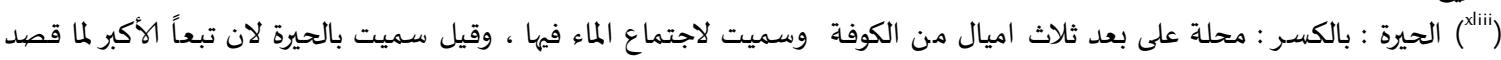

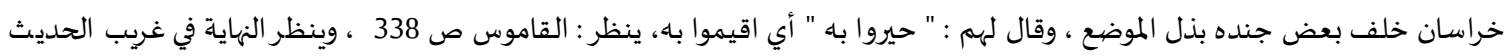

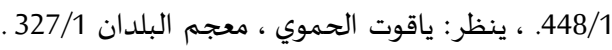

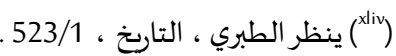

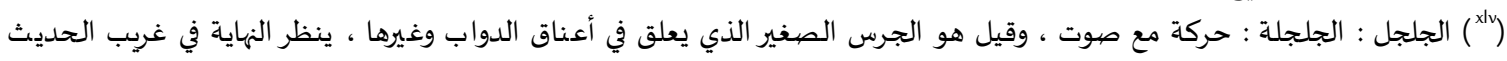

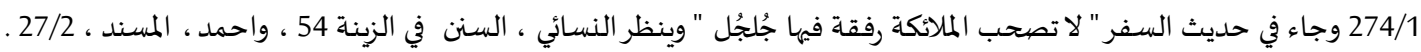

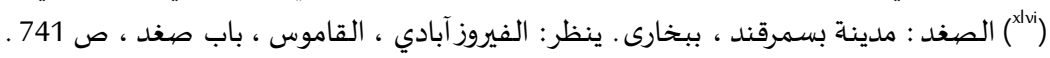

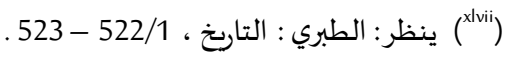
(lviii)

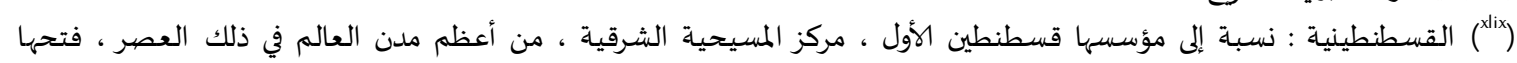

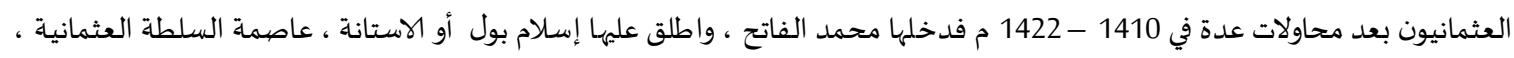

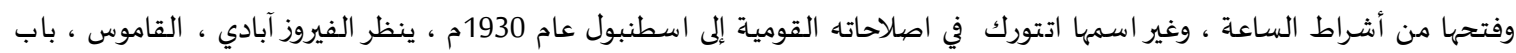

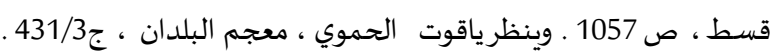

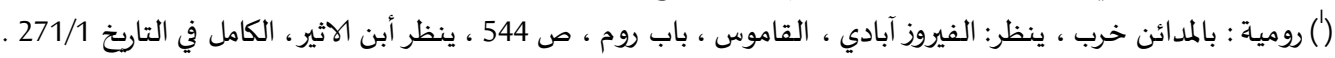

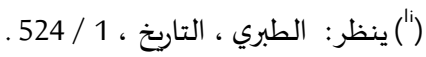
524/1 ، (ii)

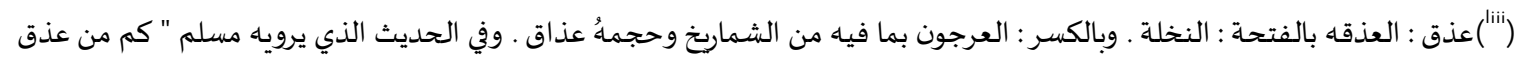

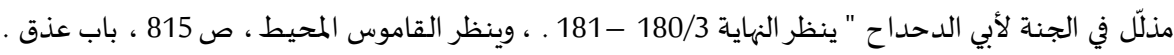

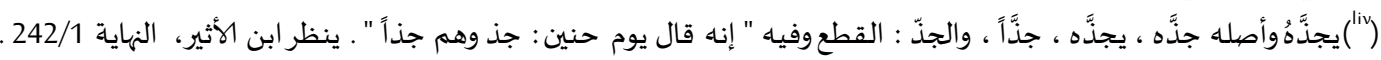

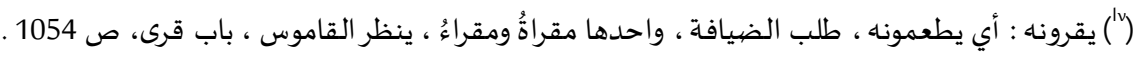


(الأحبار : واحدها حبر وفيه " سميت سورة المائدة سورة الأحبار " لقوله تعالى (( يحكم بها النبيون الذين أسلموا للذين هادوا والربانيون

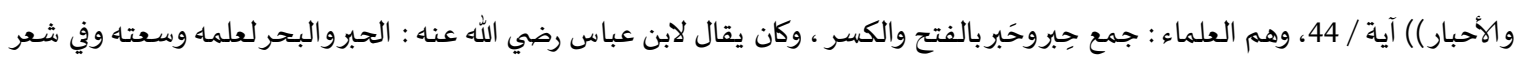

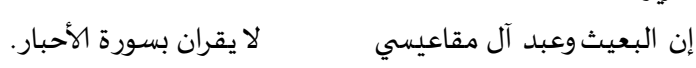

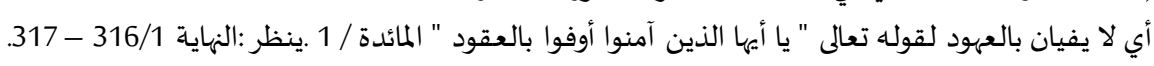

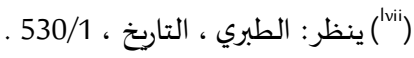

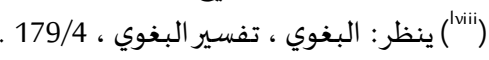

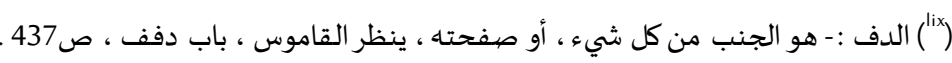

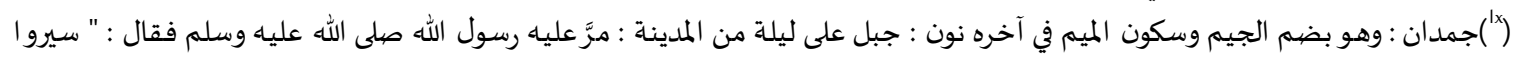

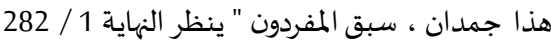

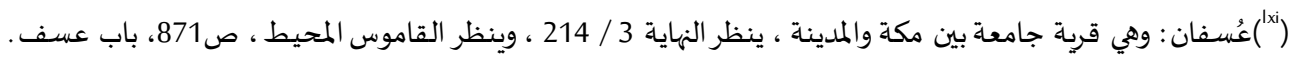

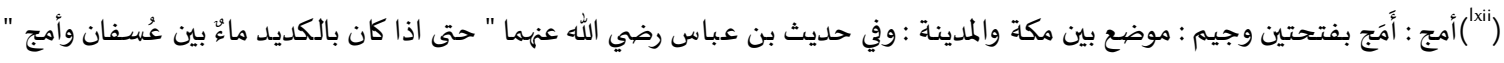
ينظر النهاية 66/1. (xiii)

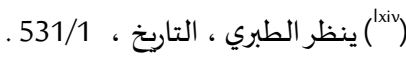

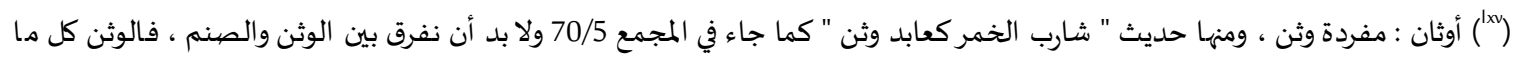

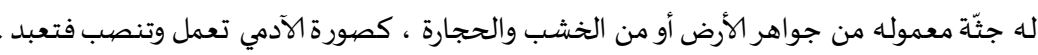

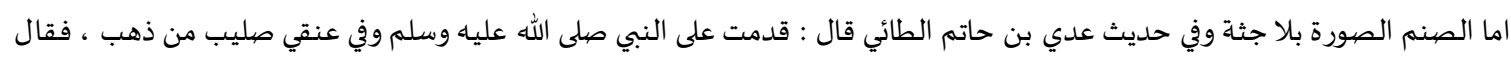

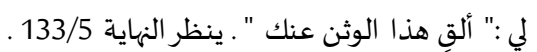
(الخصف : حصير تنسج من خوص النخل ومن الليف ، فيسوى منها شقق تلبس بيوت الاعراب . ينظر : ابن هشام ، السيرة النبوية، ص42. ( المعافر: ثياب تنسب إلى قبيلة من اليمن ، وآصله المعافري ، ثم صار اسماً لها بغير نسبة . ينظر ، ابن هشام ، السيرة النبوية ، ص42.

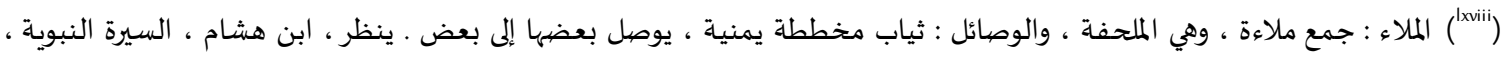

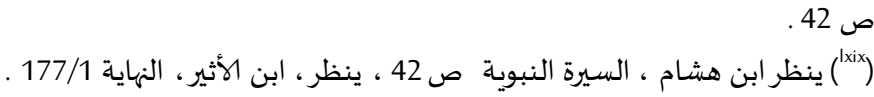

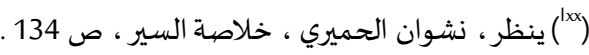

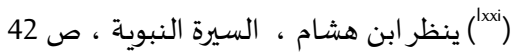

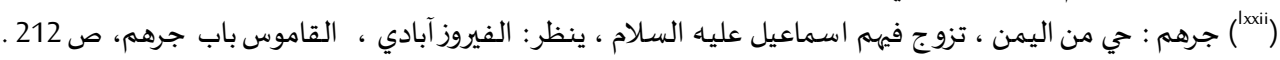

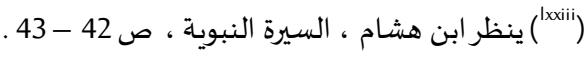

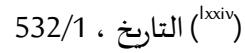

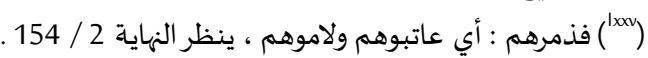

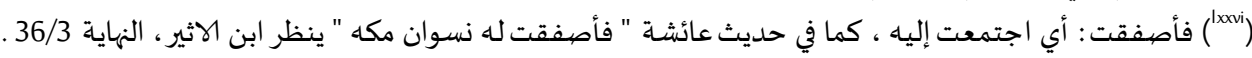
(xxvii) (lxviii)

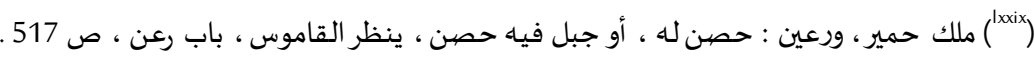

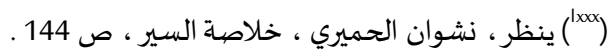

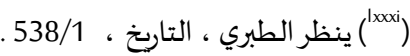

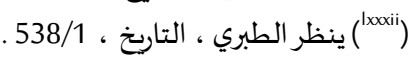

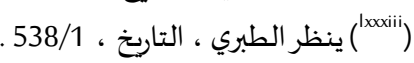




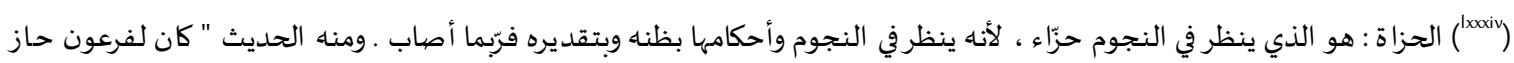

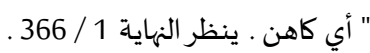

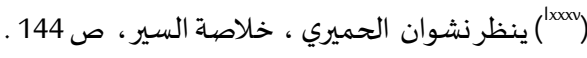

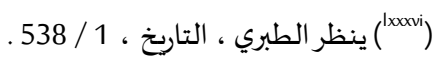

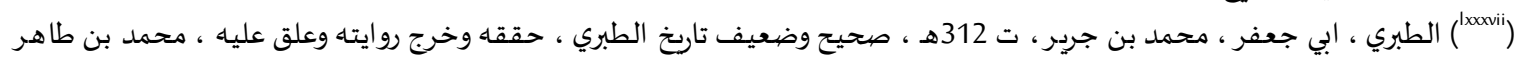

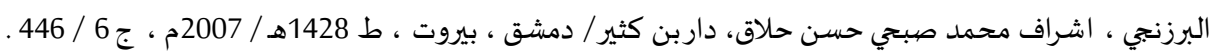
(1)xoviii)

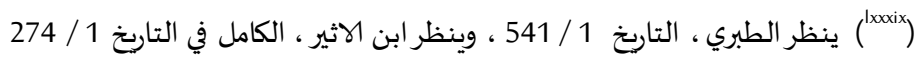

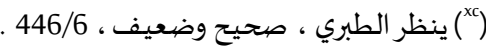

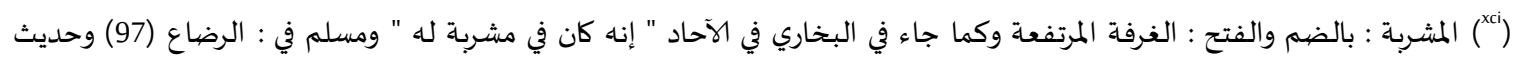

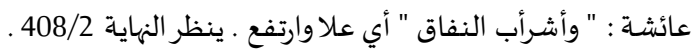
(cii)

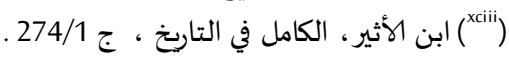

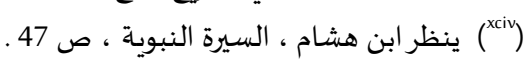

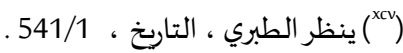

\section{المصيادر والمراجع}

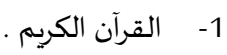

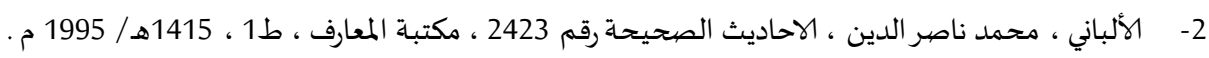

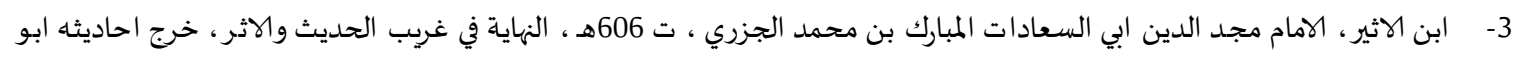

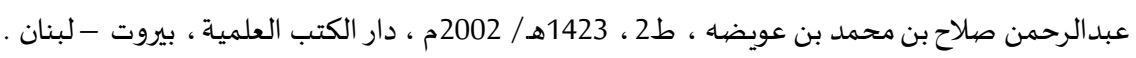

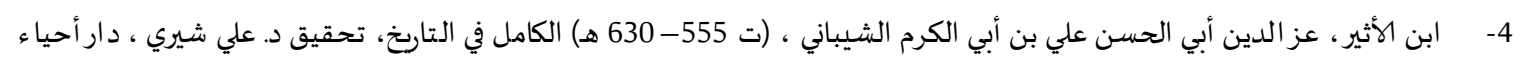

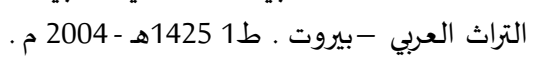

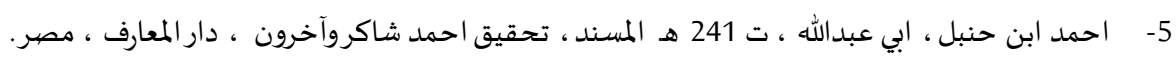

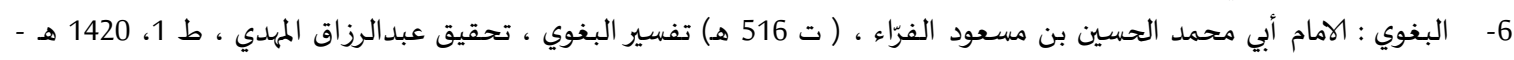

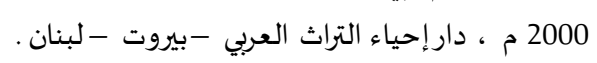

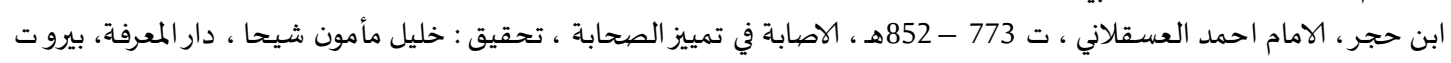

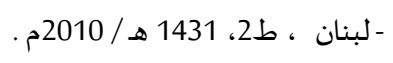

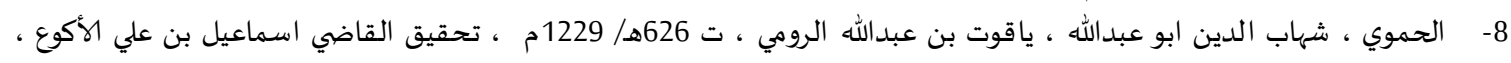
مؤسسة الرسالة ، بيروت ، ط2 ، 1995.

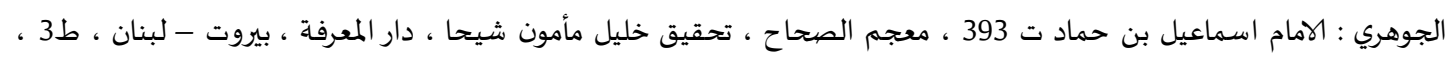
$-9$

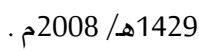
10- ابن عماد ، الامام شهاب الدين بن ابي الفلاح الحنبلي الدمشقي ، ت 142003 1032- 1089 هـ ، شذرات الذهب في أخبار من ذهب ، تحقيق

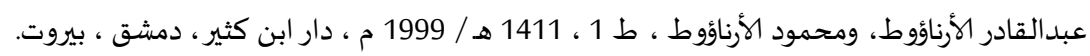

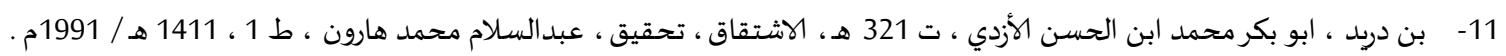

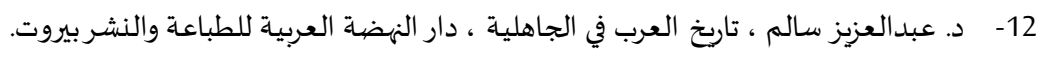

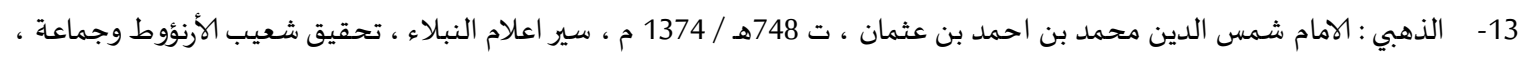
ط 2 ، 1432هـ/ 2011 م ، مؤسسة الرسالة. 
14- الذهبي ، أبي عبد الله شمس الدين ، محمد بن احمد بن عثمان ، ت 748 هـ ، ميزان الاعتدال في نقد الرجال ، تحقيق محمد بركات ،

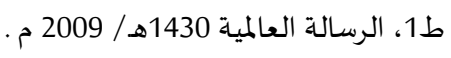

15- ابو اسحاق ، ابراهيم بن محمد بن السري بن سهل ، النحوي ، ت 311هـ ، معاني القرآن ، تحقيق عبدالجليل عبدة ، عالم الكتب ،

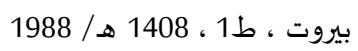

16- السهيلي : هو الامام ابو زيد العلامة الاندلسي الحافظ العلم ، صاحب التصانيف منها (الروض الانف في شرح سيرة ابن هشام ).

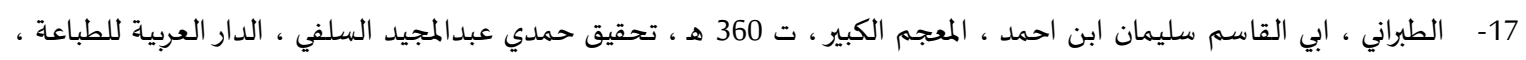
بغداد.

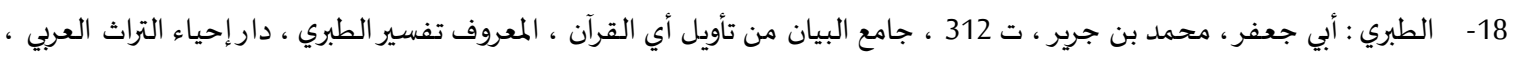

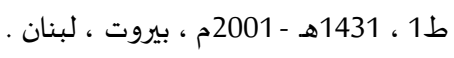

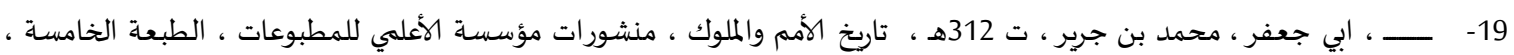

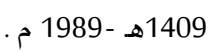

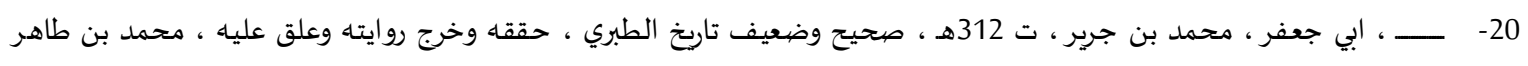

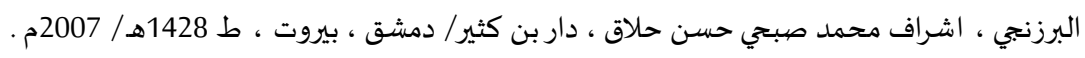

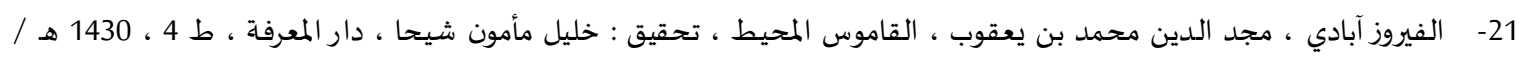
2009

22- القرطبي : ابي عبدالهه ، محمد بن احمد الانصاري ، الجامع الاحكام القرآن ، تحقيق عبدالرزاق المهدي، ط 1433 ، دار الكتاب العربي ،

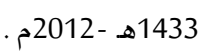

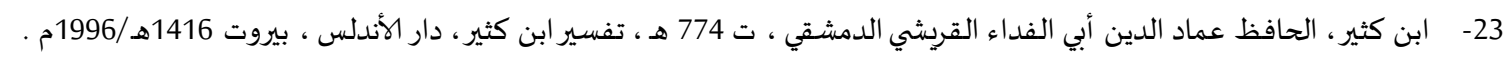

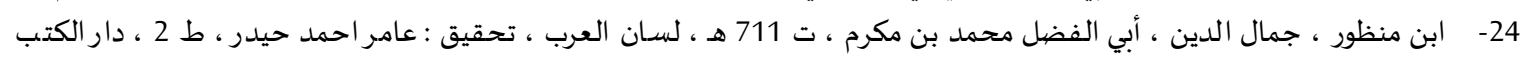

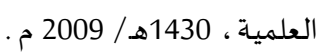

25- ابن هشام ، ابي محمد عبدالملك ، ت 218 هـ ، السيرة النبوية ، تحقيق مصطفى السقا ، ابراهيم الأبياري عبدالحفيظ شلبي ، داربن

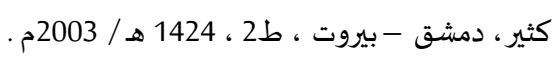

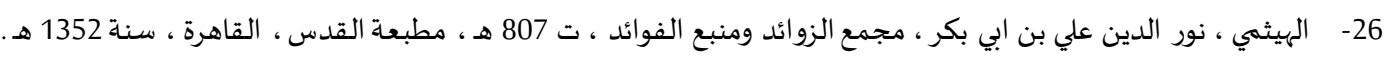

